\title{
STVARNOPRAVNA I CARINSKOPRAVNA ZAŠTITA KULTURNIH DOBARA U SVJETLU EUROPSKE ANTITERORISTIČKE POLITIKE
}

Dr. sc. Hano Ernst, docent

Pravni fakultet Sveučilišta u Zagrebu

Kristijan Poljanec, mag. iur., asistent

Ekonomski fakultet Sveučilišta u Zagrebu
UDK: $339.543: 351.853$

343.711 .7

Ur.: 23. siječnja 2017.

Pr.: 1. veljače 2017.

Izvorni znanstveni rad

\begin{abstract}
Sažetak
U radu se analiziraju međunarodna, europska $i$ hrvatska pravila u području prometa kulturnim dobrima te se autori kritički osvrću na činjenicu kako ona nisu prepoznala važnost stvarnopravnih mehanizama u borbi protiv nezakonitog prometa kulturnim dobrima. Ukazuje se na važnost privatnopravnih mehanizama u borbi protiv nezakonitog prometa kulturnim dobrima. Razmatra se problem izvoza kulturnih dobara u treće države i reakcije EU-a na iračku $i$ sirijsku krizu u pogledu uvoza kulturnih dobara. Raspravlja se o novim mjerama EU-a u pogledu regulacije uvoza kulturnih dobara iz trećih država kao dijelu sveobuhvatne agende u borbi protiv financiranja terorizma. Autori se osvrću na postojeću regulaciju unutarnjeg prometa kulturnih dobara u kontekstu slobode kretanja robe, te se analiziraju ograničenja pravnog prometa kulturnih dobara u hrvatskom pravu. Zaključuje se kako je hrvatski režim prometa kulturnim dobrima stvorio dobar okvir za borbu protiv krijumčarenja kulturnih dobara te on već sada doprinosi antiterorističkoj politici EU-a, ali i to da ima prostora za poboljšanja, posebno u privatnopravnoj sferi. Pritom se problematiziraju pitanja odabira načela lex rei sitae kao stvarnopravnog statuta za kulturna dobra, kao i pitanja vezana uz tradicionalne institute stjecanja od nevlasnika $i$ dosjelosti. U radu se iznosi nekoliko preporuka i za budući sustav zaštite kulturnih dobara u uvozu.
\end{abstract}

Ključne riječi: kulturno dobro, lex rei originis, antiteroristička politika, stjecanje od nevlasnika.

\section{UVOD}

Očuvanje i zaštita kulturne baštine jedna je od zadaća Europske unije ${ }^{1}$, propisana Ugovorom o funkcioniranju EU-a. ${ }^{2}$ Promicanje raznolikosti u međunarodnim

2 Ugovor o funkcioniranju EU, pročišćena inačica, SL C 202, 7. lipnja 2016. Dalje kao: UFEU. 
kulturnim odnosima čini važan dio uloge EU-a kao sudionika globalne politike. ${ }^{3}$ Prvenstvena zadaća EU-a je doprinositi razvoju kultura država članica, uz poštovanje njihove nacionalne i regionalne različitosti. ${ }^{4}$ Pored toga, EU je dužan voditi računa o zajedničkoj kulturnoj baštini država članica, ${ }^{5}$ što je upotpunjeno njegovom zadaćom da potiče suradnju između država članica, podupire i dopunjuje njihovo djelovanje, inter alia, u području očuvanja i zaštite kulturne baštine od europske važnosti. ${ }^{6} \mathrm{U}$ tom se smislu može reći da primarno pravo EU-a prepoznaje koegzistenciju nacionalne kulture država članica i zajedničke europske kulturne baštine. ${ }^{7}$

Kulturna dobra iz EU u značajnoj mjeri sudjeluju u međunarodnoj trgovini kulturnim dobrima. ${ }^{8}$ To se u zadnjem izvještajnom razdoblju (2008.-2014.) ponajprije odnosilo na izvoz umjetničkih djela. ${ }^{9}$ Međutim, unatoč izraženom trendu izvoza kulturnih dobara, u 2014. trgovina kulturnim dobrima se odnosila na trgovinu između država članica, ${ }^{10}$ tj. na unutarnji promet. Nažalost, pored zakonitog prometa kulturna dobra predstavljaju okosnicu međunarodnog kriminaliteta, posebno povezanog $\mathrm{s}$ terorističkim aktivnostima.

$\mathrm{U}$ ovom radu raspravljamo, $\mathrm{s}$ jedne strane, o zaštiti vanjskog, a $\mathrm{s}$ druge, o zaštiti unutarnjeg prometa kulturnih dobara u EU. Nakon uvoda, u drugom dijelu rada promatramo problem izvoza kulturnih dobara u treće države i reakcije EU-a na iračku i sirijsku krizu u pogledu uvoza kulturnih dobara te raspravljamo o najavljenim mjerama EU-a u pogledu regulacije uvoza kulturnih dobara iz trećih država kao dijelu sveobuhvatne agende u borbi protiv financiranja terorizma. U trećem dijelu rada problematiziramo postojeću regulaciju unutarnjeg prometa kulturnih dobara

3 Tako Zajednička komunikacija Europskom parlamentu i Vijeću: Ususret Strategiji EU-a za međunarodne kulturne odnose, Bruxelles, 8. lipnja 2016., JOIN(2016) 29 final, str. 2. U ovoj se Zajedničkoj komunikaciji predlažu načela za strateški pristup EU-a kulturnoj diplomaciji. Dalje kao: Ususret Strategiji... .

4 Čl. 167. st. 1. UFEU.

5 Čl. 167. st. 1. UFEU.

6 Čl. 167. st. 2. al. 2. UFEU. Riječ je o komplementarnoj nadležnosti EU. V. Čl. 6. st. 1. (c) UFEU.

7 U Komunikaciji Komisije Europskom parlamentu, Vijeću, Europskom gospodarskom i socijalnom odboru i Odboru regija: Ususret cjelovitom pristupu kulturnoj baštini u Europi, Bruxelles, 22. srpnja 2014., $\operatorname{COM}(2014) 477$ final, str. 3 stoji da „,ne postoji proturječnost među nacionalnim odgovornostima i djelovanjem EU-a: kulturna baština uvijek je i lokalna i Europska." Dalje kao: Ususret cjelovitom pristupu... .

8 Prema podatcima Eurostata, u razdoblju od 2008. do 2014. bilanca trgovine kulturnim dobrima iz EU-a je iz deficita (2.068 milijuna eura u 2008.) prešla u suficit (1.857 milijuna eura u 2014.) kao posljedica povećanja izvoza i smanjenja uvoza kulturnih dobara. Smanjenje uvoza pripisuje se ekonomskoj krizi, ali i tehnološkim promjenama. V. Eurostat: Culture Statistics, 2016 ed., str. 98. Dalje kao: KS 2016. Dostupno na http://ec.europa.eu/eurostat/web/productsstatistical-books/-/KS-04-15-737, 6. srpanj 2016., 1. prosinca 2016.

9 KS 2016, str. 100. Umjetnička djela (slike, skulptura itd.) čine $43 \%$ dobara u ukupnom izvozu prema trećim zemljama, najviše prema SAD-u. KS 2016, str. 107, 110. Najveći izvoz su imale Latvija i Cipar, dok u uvozu prednjači Poljska. Od uvoznih dobara najveći udio (31 \%) otpada na filmove, video-igrice i igraće konzole. KS 2016, str. 107. Glavni uvozni partner je Kina. KS 2016, str. 111.

10 KS 2016, str. 105. 
u kontekstu slobode kretanja robe. Posebno se osvrćemo na ograničenja pravnog prometa i izvoza kulturnih dobara u hrvatskom pravu te zaključujemo kako je hrvatsko pravo, uvevši strogi režim prometa kulturnim dobrima, stvorilo dobar javnopravni okvir za borbu protiv krijumčarenja kulturnih dobara te ono već sada doprinosi antiterorističkoj politici EU-a, premda privatnopravni mehanizmi i dalje ostaju zanemareni. Posebno se problematizira pitanje odabira načela lex rei sitae kao stvarnopravnog statuta za kulturna dobra te, oslanjajući se na teorijska i komparativna zakonodavna rješenja u ovom području, nastojimo objasniti zašto bi neka buduća kolizijska pravila EU-a trebala usvojiti načelo lex rei originis za mjerodavno načelo za stjecanje kulturnih dobara. U četvrtom dijelu ukazujemo na buduće mehanizme zaštite kulturnih dobara u europskom i nacionalnom aspektu. Pritom se kritički osvrćemo na činjenicu kako postojeći međunarodni, europski i nacionalni mehanizmi zaštite nisu prepoznali važnost privatnopravnih mehanizama u borbi protiv nezakonitog prometa kulturnim dobrima. U tom dijelu iznosimo i nekoliko preporuka za budući sustav zaštite kulturnih dobara u uvozu.

\section{ZAS̆TITA VANJSKOG PROMETA KULTURNIH DOBARA}

\subsection{Zaštita kulturnih dobara u izvozu}

Uredbom o izvozu kulturnih dobara iz $1992 .{ }^{11}$ uspostavio se jedinstven sustav kontrola izvoza kulturnih dobara s područja carinske unije u treće države. Osnovu tog sustava čine izvozne dozvole koje imaju pravnu snagu diljem EU-a i koje izdaje nadležno nacionalno tijelo države članice. ${ }^{12}$ Prema Implementacijskoj uredbi Komisije (EU) br. 1081/2012 od 9. studenog 2012. u svrhe Uredbe Vijeća (EZ) br. 116/2009 od 18. prosinca 2008. o izvozu kulturnih dobara (kodifikacija) (dalje kao: IU) postoje tri vrste dozvola: standardno odobrenje, posebno otvoreno odobrenje i opće otvoreno odobrenje. ${ }^{13}$ Standardno odobrenje koristi se u svrhu redovitog izvoza sukladno Uredbi 116/2009, ${ }^{14}$ posebno otvoreno odobrenje izdaje se u svrhu opetovanog privremenog izvoza u izložbene svrhe, ${ }^{15}$ dok se opće otvoreno odobrenje izdaje u svrhu privremenog izvoza kulturnih dobara koja čine dio stalnih muzejskih i srodnih postava. ${ }^{16}$ Time je EU uspostavio unificirani pravni okvir za tzv. vanjski izlazni promet kulturnim dobrima s područja EU-a. ${ }^{17}$

11 Uredba Vijeća (EEZ) br. 3911/92 od 9. prosinca 1992. o izvozu kulturnih dobara, SL EZ L 395, 31.12.1992., str. 1. Ta je Uredba zamijenjena kodifikacijskom Uredbom Vijeća (EZ) br. 116/2009 od 18. prosinca 2008. o izvozu kulturnih dobara, SL EU L 39, 10.12.2009., str. 1.

12 Opširnije o carinskom postupku te postupku izdavanja odobrenja za iznošenje kulturnih dobara u države članice EU vidi u: Lichtner-Kristić, M. Izvoz i iznošenje kulturnih dobara iz Hrvatske u kontekstu usklađivanja hrvatskog pravnog sustava sa pravnom stečevinom Europske unije, Zagreb, Carinski vjesnik, vol. 16, 5/2007, str. 52-71.

13 Čl. 1. IU.

14 Ćl. 2. st. 1. IU.

15 Čl. 2. st. 2. u vezi s čl. 10. IU.

16 Čl. 2. st. 3. u vezi s čl. 13. IU.

17 Prema podatcima dostupnima u Izvješću Komisije Europskom parlamentu, Vijeću i Europskom gospodarskom i socijalnom odboru o provedbi Uredbe Vijeća (EZ) br. 116/2009 od 18. prosinca 
Kulturna dobra koja podliježu izvoznoj kontroli ovise s jedne strane o nacionalnom pravu pojedine države članice, koja primjenjujući nacionalna pravila o izvozu primjenjuje i nacionalni pojam kulturnog dobra. S druge strane, kulturna dobra koja su obuhvaćena Uredbom samo su ona kulturna dobra koja su navedena na listi kategorija u Dodatku Uredbe. Time se omogućilo da države na čijim vanjskim granicama dolazi do prometa ne moraju primjenjivati sva nacionalna zakonodavstva o izvoznim ograničenjima. ${ }^{18}$ Istovremeno je, međutim, potrebno upozoriti da kontrolu putem izvoznih dozvola vrši država koja je nadležna po mjestu trajnog smještaja kulturnog dobra u trenutku podnošenja zahtjeva za izvoz, a ne prema kriteriju klasifikacije kulturnog dobra kao nacionalnog blaga.

Već nekoliko godina dolazi do intenziviranja djelovanja EU-a na polju borbe protiv financiranja terorizma nezakonitom trgovinom kulturnim dobrima. U zaključcima iz 2011. ističe se potreba razvoja specifičnih aranžmana s trećim državama radi povrata ukradenog blaga. ${ }^{19} \mathrm{U}$ istim zaključcima Vijeće je uputilo preporuku Europskoj komisiji ${ }^{20}$ da podupre države članice u efikasnoj zaštiti kulturnih dobara radi sprječavanja i borbe protiv nezakonitog trgovanja. ${ }^{21} \mathrm{U}$ travnju 2015. Europski parlament ${ }^{22}$ usvojio je Rezoluciju o zločinačkom uništavanju kulturnih lokaliteta od strane ISIL/Daesha. ${ }^{23}$ Akcijski plan EK-a iz veljače 2016. za jačanje borbe protiv financiranja terorizma ${ }^{24}$ predviđa usvajanje zakonodavnih i ne-zakonodavnih mjera

2008. o izvozu kulturnih dobara, 1. siječnja 2011.- 31. prosinca 2013., Bruxelles, 1. travnja 2015., (COM(2015) 144 final) (dalje kao: Izvješće o izvozu...) države članice su najviše izdavale standardna odobrenja (24 564) u čemu su prednjačile Ujedinjeno Kraljevstvo i Italija (Izvješće o izvozu, str. 4). To predstavlja porast u odnosu na prethodno izvještajno razdoblje od 2000. do 2010. (Izvješće o izvozu, str. 9). Slijede posebna otvorena odobrenja (946) u čemu prednjače Ujedinjeno Kraljevstvo, Nizozemska i Poljska (Izvješće o izvozu, str. 4). Konačno, izdano je i 472 općih otvorenih odobrenja u čemu prednjači Španjolska (84\%). S druge strane, EU države članice su 318 puta odbile izdati standardno odobrenje pozivanjem na zaštitu nacionalnog blaga (Izvješće o izvozu, str. 4). To predstavlja 0,4\% od ukupnog broja izdanih odobrenja. Trend niske razine odbijanja izvornih dozvola se nastavlja iz prethodnog izvještajnog razdoblja (Izvješće o izvozu, str. 10).

18 Josipović, Tatjana, Zaštita kulturnih dobara u Europskoj uniji u: Gavella, N. i dr., Europsko privatno pravo, Zagreb, Pravni fakultet, 2002., str. 106.

19 Zaključci Europskog vijeća od 13. i 14.11.2011., 17541/11 ENFOPOL 415 CULT 111 ENFOCUSTOM 143. str. 3. Dalje kao: Zaključci 2011.

20 Dalje kao: EK.

21 Zaključci 2011, str. 4.

22 Dalje kao: EP.

23 Rezolucija EP br. 2015/2649(RSP). EP je tom prilikom oštro osudio namjerno uništavanje kulturnih, arheoloških i vjerskih lokaliteta od strane ISIL-a u Siriji i Iraku te pozvao potpredsjednika EK i Visoku povjerenicu za vanjske poslove i sigurnosnu politiku da implementiraju sigurnosne mjere na vanjskim granicama EU-a radi sprječavanja da kulturna dobra iz Sirije i Iraka bude krijumčarena na područje EU-a te da zajedničkim snagama spriječe trgovinu artefaktima sirijskog i iračkog podrijetla u Europi budući da visoka koncentracija trgovine srednjo-istočnim umjetninama za svoje odredište ima europsko tržište, tržište Sjedinjenih Američkih Država i tržište Golfskog zaljeva. Dostupno na http://www. europarl.europa.eu/sides/getDoc.do?pubRef=-//EP//NONSGML+MOTION+P8-RC-20150375+0+DOC+PDF+V0//EN, 28. travnja 2015., 28. prosinca 2016.

24 Komunikacija Komisije Europskom parlamentu i Vijeću o Akcijskom planu za jačanje borbe 
za borbu protiv financiranja terorizma u nekoliko područja koja je EU prepoznao kao izvor financiranja terorističkih skupina. Najavljenim sprječavanjem premještanja sredstava i identifikacijom izvora financiranja terorizma želi se spriječiti pranje novca. ${ }^{25}$

U pogledu kulturnih dobara iz Iraka i Sirije posebno su primjenjive dvije uredbe koje određuju ograničenja u prometu kulturnim dobrima koja su nezakonito uklonjena s područja Iraka i Sirije. ${ }^{26}$ Sukladno navedenim uredbama za sirijsku baštinu zabranjen je uvoz, izvoz, prijenos ili pružanje posredničkih usluga povezanih s uvozom, izvozom ili prijenosom sirijskih kulturnih dobara te drugih predmeta arheološke, povijesne, kulturne, rijetke znanstvene ili vjerske važnosti, ako postoje temelji za sumnju da su predmeti uklonjeni iz Sirije bez pristanka njihova zakonitog vlasnika ili su uklonjeni kršenjem sirijskog prava ili međunarodnog prava, posebno ako su ti predmeti sastavni dio javnih zbirki popisanih u inventarima konzervatorskih zbirki sirijskih muzeja, arhiva, knjižnica ili inventara sirijskih vjerskih ustanova, ako postoji osnovana sumnja da su predmeti uklonjeni iz Sirije bez pristanka njihova zakonitog vlasnika ili su uklonjeni kršenjem sirijskog zakona ili Konvencije UNESCO-a o mjerama zabrane i sprječavanja nezakonitog uvoza, izvoza i prijenosa vlasništva nad kulturnim dobrima. ${ }^{27} \mathrm{Za}$ iračku baštinu vrijedi raniji režim po kojem je zabranjen uvoz ili unošenje na teritorij Zajednice; izvoz ili uklanjanje s teritorija Zajednice; i trgovanje iračkom kulturnom baštinom i drugim predmetima koji su od arheološke, povijesne, kulturne, rijetke znanstvene i vjerske važnosti ukoliko su bili nezakonito odstranjeni s lokacija u Iraku, a posebno ako (spomenuti predmeti) predstavljaju sastavni dio javnih zbirki popisanih u inventarima iračkih muzeja, arhiva ili konzervatorskih zbirki knjižnica, ili u inventarima iračkih vjerskih institucija, ili postoji opravdana sumnja da je roba odstranjena iz Iraka bez odobrenja zakonitog vlasnika ili povredom iračkih zakona i propisa. ${ }^{28}$

protiv financiranja terorizma, Bruxelles, 2. veljače 2016., COM (2016)50 final. Dostupno na http://eur-lex.europa.eu/legal-content/HR/TXT/?uri=CELEX:52016DC0050. Dalje kao: AP.

25 Najavljenim sprječavanjem premještanja sredstava i identifikacijom izvora financiranja terorizma želi se spriječiti pranje novca. Predviđa se uvođenje nadzora nad korištenjem platformi za konverziju virtualnog novca, korištenjem gotovinskog plaćanja anonimnih prepaid kartica, financijskim tokovima iz trećih zemalja. U institucionalnom pogledu, najavljuje se povećanje ovlasti financijskih obavještajnih jedinica, centralizacija nacionalnih registara bankovnih računa i računa za plaćanje te centralizacija sustava za dohvat podataka kao i zamrzavanje imovine terorista u suradnji s UN-om. V. AP, str. 4-8.

26 Uredba Vijeća (EZ) br. 1210/2003 od 7. srpnja 2003. o određenim posebnim ograničenjima gospodarskih i financijskih odnosa s Irakom i stavljanju izvan snage Uredbe (EZ) br. 2465/96, SL EZ L 169, 8.7.2003., str. 6., dalje kao: Uredba 1210/2003. V. i Uredba Vijeća (EU) br. 36/2012 od 18. siječnja 2012. o mjerama ograničavanja s obzirom na stanje u Siriji i o stavljanju izvan snage Uredbe (EU) br. 442/2011, SL L EU 16, 19.1.2012, str. 1.; Uredba Vijeća (EU) br. 1332/2013 od 13. prosinca 2013. o izmjeni Uredbe (EU) br. 36/2012 o mjerama ograničavanja s obzirom na stanje u Siriji, SL L EU 335, 14.12.2013, str. 3. Dalje kao: Uredba 36/2012.

27 Čl. 11.c Uredbe 36/2012.

28 Čl. 3. Uredbe 1210/2003. 


\subsection{Zaštita kulturnih dobara и иvozu}

Početak zakonodavnog rada na izgradnji prava EU-a o pravnom prometu kulturnim dobrima koincidira s problemom porasta međunarodnog terorizma. EU je prepoznao važnost borbe protiv terorizma, ${ }^{29}$ što uključuje borbu protiv financiranja terorizma prodajom kulturnih dobara. ${ }^{30}$ EU se zbog svog zemljopisnog položaja i činjenice da je područje na kojem žive potencijalni kupci kulturnih dobara smatra vrlo atraktivnim tržištem za nezakonitu trgovinu kulturnim blagom iz trećih zemalja. ${ }^{31}$

EU je 2014. istaknuo predanost zaštiti kulturne baštine u suradnji $s$ organizacijama poput Vijeća Europe i Organizacije UN-a za obrazovanje, znanost i kulturu(UNESCO). Istaknuto je kako su potrebne hitne mjere s obzirom na uništavanje kulturne baštine u ratnim zonama poput Iraka, Sirije i Afganistana. ${ }^{32} \mathrm{Na}$ međunarodnoj razini EU sudjeluje $\mathrm{u}$ inicijativama Ujedinjenih naroda za borbu protiv financiranja terorizma nezakonitom trgovinom kulturnim dobrima koja potječu s Bliskog istoka. ${ }^{33}$

29 V. Zaključci Europskog vijeća od 28. studenog 2008., 15049/1/08 REV 1 CRIMORG 175 ENFOPOL 206 14224/2/08 REV 2 CRIMORG 166 ENFOPOL 191, dio 12; Zaključci 2011; Zaključci Europskog vijeća od 18. prosinca 2015. EUCO 28/15, Dio drugi, t. 10. EU kontinuirano surađuje s međunarodnim organizacijama kao što su UN, Vijeće Europe, Europol, Stručna skupina za financijsko djelovanje (FATF). EU sudjeluje u međunarodnim inicijativama poput Globalne strategije UN za borbu protiv terorizma, Globalnog foruma za borbu protiv terorizma, Globalne koalicije za borbu protiv ISIL-a, itd. V. http://ec.europa.eu/culture/policy/ culture-policies/trafficking_en, 6. siječanj 2017., 7. siječanj 2017.

30 Poslije trgovine drogom $\mathrm{i}$ oružjem, trgovina ukradenim umjetninama je najunosniji posao. Šteta počinjena krađom je nemjerljiva i često je praćena devastacijom kulturne baštine. Vukšić navodi nekoliko zapanjujućih brojki: 300 milijuna USD vrijedna je najveća krađa umjetnina u povijesti čovječanstva, 6 milijardi USD procijenjena je vrijednost ukradenih djela godišnje, 16.620 međunarodnih potraga za ukradenim i nestalim umjetninama prema podatcima Interpola u 2000. g. V. Vukšić, Z., Pravni i porezni promet kulturnih dobara, Zagreb, Hrvatska pravna revija, vol. 3., 6/2003, str. 85-91. Bradamante ističe kako su oružani sukobi jedan od glavnih generatora ilegalne trgovine te kako je do porasta cijene umjetnina došlo sedamdesetih $\mathrm{i}$ osamdesetih godina. IFAR (Međunarodna fondacija za istraživanje umjetnina) radi na suzbijanja ilegalne trgovine prisiljavajući trgovce umjetnina npr. iz J. Amerike da umjetnička djela prvo šalju u zapadnoeuropske zemlje pa tek ih tada mogu pokušati uvesti u SAD. Ista navodi tri osnovna oblika kriminaliteta u vezi s kulturnim dobrima, a to su: krađa, krivotvorenje i pljačka arheoloških nalazišta, koji su redovito povezani i s pranjem novca ili drugim oblicima organiziranog kriminaliteta. Bradamante, V., Zaštita kulturne baštine po nacionalnom i međunarodnom pravu s posebnim osvrtom na hrvatsku kulturnu baštinu stradalu tijekom rata 1991.-1995., Zagreb, Pravnik, vol. 37, 1 /2003, str. 79-80.

31 V. uvodne napomene uz obrazac za javnu raspravu o uvođenje EU regulacije uvoza kulturnih dobara iz trećih zemalja, str. 6. Obrazac ankete dostupan je na https://ec.europa.eu/taxation customs/sites/taxation/files/consultation_cultural_goods_survey_en.pdf, 6. siječanj 2017., 7. siječnja 2017. Dalje kao: Javna rasprava 2016.

32 Ususret cjelovitom pristupu..., str. 11-12.

33 Kao primjer suradnje EU-a i UNESCO-a može se istaknuti trogodišnji projekt Emergency Safeguarding of the Syrian Heritage. Cilj projekta je doprinijeti uspostavi socijalne kohezije, stabilnosti i održivog razvoja kroz zaštitu i očuvanje sirijske kulturne baštine. V. više http:// www.unesco.org/new/en/safeguarding-syrian-cultural-heritage/international-initiatives/ emergency-safeguarding-of-syria-heritage/, 30. prosinca 2016. O povijesti suradnje EU-a i UNESCO-a v. Studija o sprečavanju i borbi protiv nezakonitog prometa kulturnim dobrima 
Vijeće sigurnosti UN-a (VSUN) u veljači 2015. ${ }^{34}$ osudilo je uništavanje kulturne baštine $^{35}$ Iraka i Sirije od strane Islamske države Iraka i Levanta ${ }^{36}$ i Al-Nusrah fronte. ${ }^{37}$ Pritom je istaknuto kako ISIL, ANF i povezane strane stvaraju prihod za financiranje terorističke aktivnosti od izravnog ili neizravnog sudjelovanja u teškim krađama i krijumčarenju kulturnim dobrima s arheoloških nalazišta, muzeja, knjižnica, arhiva i drugih lokaliteta u Iraku i Siriji. ${ }^{38}$ Tom je prilikom VSUN još jedanput potvrdio da sve države članice UN-a moraju prikladnim mjerama spriječiti trgovinu iračkim i sirijskim kulturnim dobrima i drugim predmetima od arheološkog, povijesnog, kulturnog, znanstvenog i vjerskog značaja, a koji su nezakonito uklonjeni s područja tih zemalja što uključuje zabranu prekogranične trgovine takvim predmetima, uz mogućnost njihova sigurnog povratka u Irak odnosno Siriju. ${ }^{39}$ U prosincu 2015. Vijeće sigurnosti je opetovano naglasilo problem financiranja terorističkih skupina prihodima od nezakonitog prometa kulturnim dobrima s područja Iraka i Sirije. ${ }^{40}$

Kao što je već istaknuto, na iračka i sirijska kulturna dobra vrijede posebne uredbe. One se, međutim, ponajprije bave propisivanjem posebnih tehnoloških, infrastrukturnih, gospodarskih, financijskih i ostalih sankcija prema pojedincima $i$ trgovačkim društvima (npr. bankama) povezanim s represivnim režimima na području Iraka i Sirije, a ne problemom nezakonitog uvoza kulturnih dobara u EU-a iz svih trećih država kao samostalnim problemom već kao dijelom šire vanjske i sigurnosne politike, o čijem nastavku ovise spomenuta ograničenja. Stoga se pokazalo da navedene uredbe nisu dovoljne u suzbijanju nezakonitog prometa jer ne pružaju sveobuhvatan odgovor na borbu protiv financiranja terorizma nezakonitim prometom kulturnim dobrima.

$\mathrm{Na}$ razini država članica postoje značajne razlike u zakonodavstvima oko nekih načelnih pitanja, poput definiranja kulturnih dobara, njihove kategorizacije, klasifikacije, načinima registracije, u nadzoru kretanja i bavljenja poslovima koji

u Europskoj uniji, CECOJI-CNRS - UMR 6224, Contract No. Home/2009/ISEC/PR/019-A2, Završno izvješće - listopad 2011, str. 40, dostupna na: http://www.do.etat.lu/voyages/Report Trafficking_in_cultural_goods_EN.pdf, 1. prosinca 2016., str. 275-277. Dalje kao: Studija. O povijesti suradnje s Međunarodnim institutom za unifikaciju privatnog prava (UNIDROIT) v. Studija, str. 275-280.

34 V. Rezoluciju VSUN br. 2199 (2015) od 12. veljače 2015, para 15. Dostupno na: http://www. un.org/press/en/2015/sc11775.doc.htm., 12. veljače 2015., 29. prosinca 2016.

35 Nakon uništenja hrama Baalshamin na sirijskom lokalitetu Palmira, u okviru UNESCO-a korišten je termin „kulturno čišćenje” pod kojim se razumijeva namjerno uništavanje materijalne i nematerijalne kulturne baštine u Iraku i Siriji. V. http://en.unesco.org/news/director-generalirina-bokova-firmly-condemns-destruction-palmyra-s-ancient-temple-baalshamin, 30. prosinca 2016.

36 Poznate i pod nazivom Daesh. Dalje kao: ISIL.

37 Dalje kao: ANF.

38 Rezolucija 2199, para. 16. O ovom problemu v. detaljno u Willett, H. D., Ill-Goten Gains: A Response to the Islamic State's Profits from the Illicit Antiquities Market, Arizona Law Review, vol. 58, 3/2016, str. 831-865.

39 Rezolucija 2199, para. 16. Glede Iraka, to vrijedi počevši od 6. 8. 1990., a glede Sirije od 15.3.2011.

40 V. Rezoluciju VSUN br. 2253(2015) od 17.12.2015., dostupnu na: https://www.un.org/press/ en/2015/sc12168.doc.htm., 17. prosinca 2015., 29. prosinca 2016. 
uključuju kulturna dobra, uključujući kupnje putem interneta. ${ }^{41}$ Nedostatak pravnog okvira za uvozne kontrole ističe se kao poseban problem. ${ }^{42} \mathrm{U}$ pogledu uvoza kulturnih dobara iz trećih zemalja pokazalo se kako nema zabrane uvoza kulturnog dobra u države članice i kako se kulturna dobra provjeravaju kao i svako drugo dobro. ${ }^{43}$ Uvozne dozvole su rijetke, uz iznimke Grčke i Italije. ${ }^{44}$

Slijedom toga, mišljenje je Komisije da postoji potreba za popunjavanjem pravne praznine u regulaciji vanjskog ulaznog prometa na supranacionalnoj razini. Slično kao i 1993. ponovno se prepoznaje uloga carinskih službi u suzbijanju i sprečavanju nezakonitog trgovanja kulturnim dobrima na vanjskim granicama EU-a. Nedostatci regulacije vanjskog ulaznog prometa nastoje se popuniti carinskim instrumentima sada u novom ruhu i s novim poticajem borbe protiv terorizma. U tom smislu EU se pojavljuje kao borac za zaštitu svjetske kulturne baštine.

Na razini EU-a još uvijek ne postoje zajednička carinska pravila o uvozu nezakonito otuđenih kulturnih dobara iz trećih država. Stoga je uvođenje regulacije o uvozu kulturnih dobara iz trećih država u EU jedna od Akcijskim planom najavljenih zakonodavnih mjera ${ }^{45}$ Kulturna dobra identificirana su kao jedan od primarnih izvora prihoda za financiranje terorizma. ${ }^{46}$ Stoga uništavanje izvora prihoda terorističkih organizacija uključuje usvajanje zakonodavnog prijedloga radi borbe protiv nezakonite trgovine kulturnim dobrima. U tom smislu Vijeće je u zaključcima iz veljače 2016. uputilo poziv EK da hitno unaprijedi borbu protiv nezakonite trgovine kulturnim dobrima te da što prije predloži zakonodavne mjere radi borbe protiv nezakonite trgovine kulturnim predmetima ${ }^{47}$ Kao rezultat navedenih inicijativa, u tijeku je javna rasprava $^{48}$ o budućem zakonodavnom okviru. ${ }^{49}$

U smislu Uredbi 1210/2003 i 1332/2013 nedopušten uvoz dobara iz Iraka i Sirije bio bi onaj kod kojeg su carinske službe EU-a utvrdile postojanje nekog od razloga za zabranu uvoza. Međutim, nije isključeno da se kulturno dobro ipak nezakonito uveze i zatekne na području EU-a. Nekoliko je mogućih slabih točaka postojećeg sustava zbog kojih bi do toga moglo doći. Pored problema tereta dokazivanja podrijetla robe, ${ }^{50}$

41 Vidi više u Studija, str. 69 et seq.

42 Studija, str. 193.

43 Studija, str. 122. Prema nalazima Studije, jedino Njemačka i Malta imaju nešto temeljitije provjere uvezenih kulturnih dobara u odnosu na druge države članice EU-a; no ni te provjere ne odstupaju mnogo od uobičajene prakse u EU.

44 Studija, str. 123.

45 Zakonodavni prijedlog protiv nezakonite trgovine kulturnim dobrima očekuje se najkasnije do drugog tromjesečja 2017. AP, str. 13. V. Aneks Komunikaciji Komisije Europskom parlamentu i Vijeću: Akcijski plan za jačanje borbe protiv financiranja terorizma, COM(2016) 50 final, str. 4.

46 AP, 12-13.

47 Zaključci Europskog vijeća od 12. veljače 2016. EUCO 50/16, t. 12.

48 Tekst upitnika je dostupan na: https://ec.europa.eu/taxation_customs/consultations-getinvolved/customs-consultations/consultation-rules-import-cultural-goods_en. (28.12.2016.).

49 V. infra.

50 Razlog takvoj situaciji može se tražiti u nedostatku obučenih carinskih službenika, poteškoćama kod utvrđivanja podrijetla artefakta mjerodavnog prava, poteškoćama pri utvrđivanju je li kulturno dobro nezakonito odneseno etc. Javna rasprava, str. 8. V. i Peters, R., The Protection of Cultural Property in EU Law: Status Quo and Future Perspectives, u: Desmarais, F. (ur.), 
poteškoće pri kontroli carinskim službama stvara unos kulturnih dobara kao turističkih suvenira. Jedna od mogućih slabosti postojećeg sustava, koja omogućava relativno lak unos kulturnih dobara sa Srednjeg Istoka, vidi se u činjenici kako se turisti i putnici vraćaju u EU s malim suvenirima koje ne prijavljuju carinskim službama pri ulasku na carinsko područje EU-a. ${ }^{51}$ Pritom je moguće je da je takav suvenir nezakonito oduzet vlasniku ili lokalnoj instituciji. Ako carinske službe i utvrde da turist nosi kakav manji predmet (npr. kipić, posudicu ili novčić), eventualni postupak utvrđivanja podrijetla i načina na koji je „suvenir” stigao do kupca nije jednostavan. ${ }^{52}$

Ako bi se iračko odnosno sirijsko kulturno dobro našlo na području EU-a unatoč zabranama, treba uzeti da se ono ne nalazi u zakonitom prometu države članice. Ono se našlo na njezinom području mimo propisanih uvoznih formalnosti. Spomenute uredbe ne rješavaju pitanje kako postupati s kulturnim dobrom koje se propustom carinskih službi našlo na teritoriju EU-a. Na prvi pogled se nameće odgovor kako bi takvo dobro, ako i kada ga se pronađe, trebalo vratiti u zemlju podrijetla. Međutim, upravo nemogućnost utvrđivanja zemlje podrijetla i vlasnika, kao i sveprisutna opasnost od uništenja ili ponovnog stavljanja u nezakonit promet, može predstavljati stvarnu i pravnu prepreku povratku.

Premda je AP 2016. najavio kako će „Komisija razmotriti opsežniji odgovor na borbu protiv financiranja terorizma putem nezakonite trgovine kulturnim dobrima, bez obzira na zemlju podrijetla, kako bi se neki od tih problema riješili”, tekuća javna rasprava o budućoj regulaciji uvoza kulturnih dobara iz trećih zemalja nažalost se ne dotiče pitanja postupka utvrđivanja vlasništva uvezenog kulturnog dobra. U javnoj raspravi, među različitim mjerama koje je EK predložio u borbi protiv nezakonitog prometa kulturnim dobrima iz trećih zemalja, ne spominje se niti jedna mjera koja bi se ticala privatnopravnih instrumenata. ${ }^{53}$

Iz javne rasprave može se zaključiti kako će se eventualna buduća regulacija uvoza kulturnih dobara iz trećih zemalja u osnovi temeljiti na javnopravnom sustavu odobrenja $^{54}$ - svojevrsnoj ,zrcalnoj slici” sustava izvoznih odobrenja prema Uredbi

Countering Illicit Trade in Cultural Goods, 2015., str. 146.

51 Javna rasprava, str. 8 .

52 Tako primjerice turist može kupiti neki predmet na tržnici ili ulici; ili može kupiti predmet grčko-rimskog stila na proputovanju kroz više država koje dijele antičku kulturu, pri čemu će biti teško utvrditi potječe li predmet iz antičkog mjesta Palmire ili turskog Izmira prije ulaska u carinsko područje EU-a na Cipru ili Grčkoj.

53 Javna rasprava 2016., str. 12.

54 Tako se u pojmovniku uz javnu raspravu izvozni certifikat definira kao upravni dokument koji je izdalo nadležno tijelo treće države, kojim se odobrava izvoz kulturnog dobra u skladu s pravom treće države. Uvozna dozvola definira se kao upravni dokument koji izdaju carinske službe EU-a ili nadležno tijelo države članice, na zahtjev osobe koje se to tiče, a kojim se odobrava uvoz kulturnog dobra u skladu s pravom EU-a. Konačno, postoji i vlastiti certifikat koji bi uvoznik podnosio carinskim službama EU-a u obliku potvrde kojom se dokazuje da je kulturno dobro izvezeno iz treće države u skladu s pravom treće države. Takav certifikat će morati pratiti isprava s podatcima potrebnim za identifikaciju kulturnog dobra. V. Pojmovnik uz Javnu raspravu 2016., str. 7. Ovako zamišljen sustav zapravo uvodi svojevrsnu „europsku putovnicu” za kulturna dobra iz trećih država. V. Groenen, A., A Passport for Cultural Goods, predavanje održano na 21st Ius Commune Congress, Maastricht University, 25. studeni 2016, dostupno na: http://www.iuscommune.eu/html/activities/2016/2016-11-24/workshop_11b_Groenen.pdf., 
116/2009 u slučaju izvoza kulturnih dobara iz EU-a. ${ }^{55}$ Manje restriktivno rješenje bilo bi da buduća regulacija uvoza kulturnih dobara iz trećih zemalja usvoji odredbu prema kojoj bi muzeji u EU (zemlji članici prvog ulaska) bili privremeni repozitoriji nezakonito uvezenih kulturnih dobara koje je zaplijenila carinska služba države članice EU-a, do trenutka dok se ne steknu uvjeti za povrat vlasniku odnosno nadležnim institucijama u utvrđenoj zemlji podrijetla. ${ }^{56}$

Do tada, dopuštenost uvoza kulturnih dobara iz trećih država uvelike ostaje prepušteno nacionalnim zakonodavstvima, uz eventualnu primjenu dviju konvencija od pojedine države koja ih je ratificirala. U tom smislu bi se izvoz, uvoz i prijenos vlasništva kulturnog dobra suprotan odredbama UNESCO Konvencije također smatrao nezakonitim. ${ }^{57} \mathrm{U}$ smislu UNIDROIT konvencije odnošenje kulturnog dobra suprotno pravilima o izvozu kulturnih dobara radi njihove zaštite bi se smatrao nezakonitim izvozom. ${ }^{58}$ Ako bi te konvencije bile uključene u nacionalne pravne poretke, ostvarivanje obilježja nezakonitosti iz dviju konvencija ujedno bi predstavljalo povredu nacionalnog prava. ${ }^{59}$

UNESCO odnosno UNIDROIT konvencija imaju ograničeno teritorijalno područje primjene između država koje su stranke konvencije.$^{60} \mathrm{U}$ tom smislu će se konvencijske mjere sprječavanja stjecanja kulturnih dobara muzeja i sličnih ustanova u nekoj državi članici EU, ${ }^{61}$ mjere zabrane uvoza ukradenog muzejskog ili vjerskog kulturnog blaga u neku državu članicu EU-a ${ }^{62}$ mjere povrata kulturnog blaga iz države članice EU-a u neku drugu državu podrijetla, ${ }^{63}$ moći primjenjivati samo ako su uvozna država članica EU-a i država podrijetla stranke UNESCO konvencije. ${ }^{64}$

24. studenog 2016., 31.prosinca 2016.

55 Kontrola uvoza ima dobar primjer u američkom pravu još od sedamdesetih godina prošlog stoljeća kada su donesena posebna pravila o zabrani uvoza određenih pretkolumbijskih kulturnih dobara. Sukladno tim pravilima, uvoz monumentalnih ili arhitektonskih skulpturalnih murala nakon njihovog stupanja na snagu zabranjen je bez posebne potvrde države izvoznice kojom se potvrđuje da je izvoz dopušten. 19 USC §2092(1). V. Gonzalez, M. A., New Legal Tools to Curb the Illicit Traffic of Pre-Columbian Antiquities, Colum. J. Transnat'1 L. vol. 12, 1973., str. 316.; McAlee, J., From the Boston Raphael to the Peruvian Pots: Limitations on the Importation of Art Into the United States, Dick. L. Rev. vol. 85., 1980., str. 565.

56 Takva se mogućnost izravno spominje u obrascu Javne rasprave, pitanje 6, str. 13

57 Čl. 3. UNESCO Konvencije o mjerama za zabranu i sprečavanje nezakonitog uvoza, izvoza te prijenosa vlasništva na kulturnim dobrima, Pariz, 14. studeni 1970. Dalje kao: UNESCO konvencija.

58 Čl. 5. st. 2. UNIDROIT konvencije o ukradenim ili nezakonito izvezenim kulturnim dobrima, Rim, 24. lipnja 1995. Dalje kao: UNIDROIT konvencija.

59 Tako međunarodne konvencije, uključujući UNESCO i UNDROIT konvencije, imaju neposrednu primjenu upravo u graničnim državama članicama koje su posebno izložene rizicima nezakonitog uvoza iz trećih zemalja - Bugarskoj, Hrvatskoj i Rumunjskoj. V. Studija, str. 158 .

60 Čl. 21. UNESCO konvencije. Čl. 10. st. 2. UNIDROIT konvencije.

61 Čl. 7. (a) UNESCO konvencije.

62 Čl. 7. (b) (i) UNESCO konvencije.

63 Čl. 7. (b) (ii) UNESCO konvencije.

64 Prema sadašnjem stanju, primjerice, egipatsko kulturno dobro može ući npr. kroz Maltu, koja nije stranka UNESCO konvencije bez primjene konvencije, a kroz Republiku Hrvatsku uz primjenu konvencija. 
I pravo da u slučaju povrata pošteni stjecatelj zahtijeva poštenu naknadu od države podrijetla $^{65}$ ovisi o polju primjene rationae teritorii. Glede UNIDROIT konvencije njezine odredbe o povratu nezakonito izvezenog kulturnog dobra, ${ }^{66}$ odredbe o plaćanju naknade poštenom posjedniku ${ }^{67}$ uz mogućnost zadržavanja ili prijenosa vlasništva ${ }^{68}$ također će ovisiti o tomu jesu li država članica EU-a kao država unošenja i država koja traži povrat stranke konvencije. Stoga ove konvencije ne mogu popuniti pravnu prazninu u nedostatku vlastitih EU pravila o uvozu kulturnih dobara.

\section{ZAŠTITA UNUTARNJEG PROMETA KULTURNIM DOBRIMA}

\subsection{Kulturna dobra i sloboda kretanja roba}

Ideja o zaštiti unutarnjeg prometa kulturnim dobrima počiva na principijelnom provođenju ideje o slobodi kretanja roba unutar EU-a. Kultura se može utjeloviti kroz materijalna (nepokretna i pokretna) te nematerijalna kulturna dobra. ${ }^{69}$ Prema shvaćanjima Suda EU-a, kulturno (materijalno) dobro, bez obzira na obilježja koja ga razlikuju od druge robe, je roba u mjeri u kojoj može imati novčanu vrijednost i može biti predmet komercijalnih transakcija. Stoga se pravila unutarnjeg tržišta primjenjuju i na kretanje kulturnih dobara. ${ }^{70}$ Tu se ponaprije misli na pravila unutarnjeg tržišta

65 Čl. 7 (b) (ii) Konvencije. $C f$. čl. 6. UNIDROIT konvencije.

66 Čl. 5. UNIDROIT konvencije.

67 Čl. 6. st. 1. UNIDROIT konvencije.

68 Čl. 6. st. 3. UNIDROIT konvencije.

69 Prott, L. V.; O'Keefe, P., 'Cultural Heritage' or 'Cultural Property', International Journal of Cultural Property, vol. 1, 2/1992, str. 307-308. U skladu s hrvatskim pozitivnim pravom u ovom se radu koristi pojam „kulturno dobro”. Literatura ukazuje da „hrvatski termin „kulturno dobro" asocira vrijednost koja je od interesa za širu društvenu zajednicu, a pritom ne isključuje ni vlasništvo ni mogućnost gospodarske upotrebe, ali im ne pridaje prioritetni značaj. K tome je riječ „dobro” semantički dovoljno široka i apstraktna da može pored pokretnih i nepokretnih materijalnih objekata uključivati i nematerijalnu baštinu". Šošić, T. M, Pojam kulturne baštine međunarodno pravni pogled, Split, ZRPF, vol. 51, 4/2014., str. 838. Engleski ekvivalent pojma „kulturno dobro” je cultural property. U pravnom smislu se u engleskoj terminologiji prvi put javlja 1954. u Haaškoj konvenciji za zaštitu kulturne imovine u slučaju oružanog sukoba. Pojam property prednost daje imovinskopravnoj, vlasničkoj komponenti kulturnog dobra. Po Lyndelu i $O$ 'Keefeu, koncept property implicira pravo vlasništva koje podrazumijeva isključivo pravo korištenja. Prott, L. V.; O'Keefe, P., op. cit., str. 310. Smatraju kako upotreba izraza cultural property ponaprije ističe vlasnikov interes za komoditizacijom kulturnog dobra u odnosu na zaštitu i očuvanja toga dobra za buduće generacije. Stoga predlažu da se pojam cultural property zamijeni s pojmom cultural heritage, tj. kulturnom baštinom. Smatraju da ovaj drugi pojam jasnije ukazuje kako kulturno dobro nije samo imovina već uključuje i nematerijalna dobra, koja treba čuvati i prenositi budućim generacijama. ibid., str., 311. Suglasno Blake, J., On Defining the Cultural Heritage, International and Comparative Law Quarterly, vol. 49, 1/2000, str. 61-85. O odnosu globalizacije i razvoju pravnog okvira za zaštitu kulturnih dobara v. Casini, L., "Italian Hours": The globalization of cultural property law, International Journal of Constitutional Law, vol. 9, 2/2011, str. 369-393.

70 Presuda u predmetu 7/68, Komisija Europskih zajednica protiv Italije (Italian Art Treasures), EU:C:1968:51, dio B, para 1. Ovdje treba istaknuti kako je EU ratificirao Konvenciju o zaštiti i promociji različitosti kulturnih izričaja, Pariz, 20. listopada 2005. U t. 19. Preambule te 
o slobodi kretanja roba, ${ }^{71}$ uključujući pravila o zabrani uvoznih odnosno izvoznih količinskih ograničenja i svih mjera s istovrsnim učinkom u trgovini između država članica. ${ }^{72}$ Međutim, načelne zabrane količinskih ograničenja i mjera s istovrsnim učinkom ne isključuju zabrane uvoza, izvoza i provoza robe koji su opravdani, inter alia, razlozima zaštite nacionalnog blaga umjetničke, povijesne ili arheološke vrijednosti ${ }^{73}$ pa zaštita nacionalnih umjetničkih, povijesnih ili arheoloških artefakata kao materijalnih kulturnih dobara neke države članice EU-a može biti razlog za zabranu njihova slobodnog prometa tržištem EU-a.

Pritom treba istaknuti da je pojam nacionalnog blaga iznimno sporan. ${ }^{74}$ Nacionalno blago nije definirano pravom EU-a. Nacionalni karakter upućuje da se radi o dobrima od važnosti za državu članicu, ali nije jasno niti je li potrebno da dobro bude na neki način nacionalno obilježeno, ${ }^{75}$ niti što ako je riječ o dobru koje je važno za dvije ili više država članica. Kako npr. tretirati suvremena umjetnička djela čija se važnost za naciju tek treba potvrditi i koja nerijetko postanu slavna i cijenjena desetljećima nakon autorove smrti? ${ }^{76}$ Radi se o iznimno teškim pitanjima, a u smislu opravdanja zabrana odnosno ograničenja korisno je voditi računa da EU brine o

konvencije istaknuto je kako „(...) kulturna dobra (...) imaju i gospodarsku i kulturnu prirodu, jer povezuju identitete, vrijednosti i značenja; iz tog razloga ne smije se smatrati da ona imaju isključivo trgovačku vrijednost."

71 Tako i Studija, str. 40.

72 Čl. 34. i 35. UFEU. Gormley navodi porez na izvoz povijesne, umjetničke, arheološke i etnografske vrijednosti kao primjer mjera po učinku ekvivalentnih carinskim pristojbama. Opširnije u Gormley, L. W., EU Law of Free Movement of Goods and Customs Union, Oxford, Oxford University Press, 2009., str. 387.

73 Čl. 36. UFEU.

74 O mogućim kriterijima za određivanje „,nacionalnosti” kulturnih dobara v. Müller, M. M., Cultural Heritage Protection: Legitimacy, Property, and Functionalism, International Journal of Cultural Property, vol. 7, 2/1998., str. 401-402. O pojmu ,zajedničke baštine čovječanstva” u odnosu na „nacionalnu kulturnu baštinu”, v. ibid., str., 403-404.

75 V. u tom smislu. Biondi, A., The Merchant, the Thief \& the Citizen: the Circulation of Works of Art within the European Union, Common Market Law Review, vol. 34, 5/1997, str. 1181. O pojmu „nacionalno blago” u smislu UFEU v. Stamatoudi, I. A., Cultural Property Law and Restitution A Commentary to International Conventions and European Union Law, Cheltenham, UK; Northampton, MA, USA, IHC series in heritage management, Edward Elgar, 2011., str. 117-133.

76 U komparativnoj literaturi postoje razna stajališta. Gormley, L. W., op. cit., str. 478. navodi kako će suvremena djela samo iznimno moći biti pokrivena iznimkama iz UFEU-a. Postoje shvaćanja da bi trebalo razlikovati arheološka i povijesna djela s jedne strane i umjetnička djela, s druge (tako Oliver, P., Free Movement of Goods in the European Community: under Articles 28 to 30 of the EC Treaty, London, Sweet\&Maxwell, 2003., str. 285.). Takav pristup može se razumjeti jer je poveznica između arheoloških i povijesnih predmeta zapravo starost i prepoznatljivost. Naime, radi se o predmetima za koje se već može reći jesu li nacionalnog značaja, imajući u vidu njihov doprinos nacionalnom identitetu i kulturi. Kod umjetničkih djela, pogotovo kod djela suvremene umjetnosti, to je već teže procijeniti jer sama tržišna vrijednost koju postižu nije dovoljan pokazatelj za zaključak da su doista toliko vrijedna da bi imala nacionalnu važnost. Postoje shvaćanja da bi se sva umjetnička djela mogla podvesti pod pojam nacionalnog blaga ako se prihvati da pojam nacionalnog blaga može biti tumačen kao viši pojam za umjetnička djela za koja se može kazati da pripadaju naciji. Tako Gormley, L. W., op. cit., str. 479. 
nacionalnoj baštini Zajednice, što upućuje na zaštitu prema trećim državama, a ne i državama članicama. Premda čl. 36. UFEU-a predviđa zaštitu nacionalnog blago kao opravdanje za količinska ograničenja i mjere s istovrsnim učinkom ne čini se da na razini EU-a postoji konsenzus oko toga koja bi mjera zadovoljavala tu pretpostavku. ${ }^{77}$

Jednako tako, EU, a niti nacionalni pravni sustavi nisu do sada primijenili unutarnju kontrolu prometa kao mjeru borbe protiv terorizma. Okolnost da je neko kulturno dobro izvor financiranja terorističkih aktivnosti trebalo bi razmotriti kao mogući razlog za opravdanje mjere zabrane ili ograničenja izvoza u smislu čl. 36 . UFEU-a. S obzirom na to da EU do sada nije razmotrio poseban problem izvoza kulturnih dobara iz Iraka i Sirije koji ne bi bili po nacionalnom pravu države članice tretirani kao kulturno dobro, a koji su već dospjeli na teritorij EU-a, čini se da bi bilo korisno razmotriti upravo takve nacionalne (ili europske) mjere, budući da sloboda kretanja takvih kulturnih dobara pa i unutar EU-a ne pridonosi provedbi europske antiterorističke politike. Pritom treba voditi računa da se eventualna ograničenja ili zabrane uvoza, izvoza ili provoza robe iz čl. 36. UFEU-a moraju, inter alia, opravdati razlozima zaštite nacionalnog blaga umjetničke, povijesne ili arheološke vrijednosti. To znači da samo ona kulturna dobra koja je država članica, u okviru nacionalnog zakonodavstva ili administrativnih postupaka, kategorizirala ili definirala kao nacionalno blago koje ima umjetničku, povijesnu ili arheološku vrijednost u smislu članka 36. UFEU-a uživa zaštitu.

Pritom također ne treba ispustiti iz vida da se istodobno na većinu država članica EU-a primjenjuje međunarodnopravni okvir zaštite kulturnih dobara koji se razvija desetljećima kroz dva temeljna međunarodnopravna instrumenta za zaštitu kulturne baštine - UNESCO Konvenciju o mjerama za zabranu i sprečavanje nezakonitog uvoza, izvoza te prijenosa vlasništva na kulturnim dobrima ${ }^{78}$ te njoj komplementarnu ${ }^{79}$ Konvenciju UNIDROIT o ukradenim ili nezakonito izvezenim kulturnim dobrima. ${ }^{80}$ Međutim, od onih članica koje su ratificirale UNESCO Konvenciju (a to nisu sve), neke su izjavile rezerve na pojedine temeljne odredbe ${ }^{81}$ što stvara poteškoće u primjeni sustava koji bi trebao olakšati povrat kulturnih dobara. ${ }^{82}$

Upravo zbog navedenog postoji mogućnost da u nekim slučajevima pravila o slobodnom kretanju roba unutar EU-a pogoduju prometu nezakonito izvezenih

77 Niti u i citranom slučaju Italian Art Treasures ovo pitanje nije riješeno, budući da prema stajalištu Suda konkretna mjera nije niti potpadala pod čl. 36. UFEU-a, jer se nije radilo o kvantitativnom ograničenju.

78 Konvenciju su ratificirale sve države članice EU-a izuzev Irske, Latvije i Malte.

79 Studija, str. 203.

80 Konvenciju su ratificirale sve države članice EU-a izuzev Austrije, Belgije, Bugarske, Češke, Estonije, Irske, Latvije, Luksemburga, Malte, Njemačke, Poljske i Ujedinjenog Kraljevstva. U prosincu 2011. Europsko vijeće je zaključkom pozvalo države članice da razmotre ratifikaciju dviju konvencija. V. Zaključci 2011, str. 3. U travnju 2015. to je isto učinio i Europski parlament u t. 18. Rezolucije br. 2015/2649(RSP). Detaljno o dvjema konvencijama v. Stamatoudi, I. A., op. cit., str. 29-111.

81 Primjerice, Francuska, Belgija i Ujedinjeno Kraljevstvo izjavile su rezerve na pojam kulturno dobro suzivši njegov doseg na kulturna dobra određene starosti ili novčane vrijednosti. Studija, str. 155 .

82 Studija, str. 201-203. 
odnosno ukradenih kulturnih dobara koja nisu zaštićena kao takva u državi članici iz koje se izvoze u drugu državu članicu. U tim slučajevima izvozno ograničenje bilo bi učinkovita mjera imobilizacije kulturnog dobra u jednoj državi članici, premda je teško za očekivati da bi ono bilo uvedeno u onim članicama koje nisu ratificirale niti UNESCO-ovu konvenciju. Razlike u nacionalnim pravnim sustavima u području prometa kulturnim dobrima, razlike u metodama transponiranja europskog i međunarodnog prava u nacionalna prava ${ }^{83}$ kao i nepostojanje sveobuhvatne EU regulacije, omogućava nezakonit promet kulturnih dobara, ${ }^{84}$ posebice iz država nečlanica kroz zemlje članice koje nemaju regulaciju u tom području ili je ona slaba. ${ }^{85}$ Tomu doprinose i nedostatci u operativnoj i tehničkoj suradnji carinskih službi. ${ }^{86}$ Kritike postojećeg pravnog sustava idu i dalje, pa se istič ${ }^{87}$ da je sustav EU-a u području kretanja kulturnih dobara „neoperativan” i da ovisi o nacionalnim pravima država članica.

\subsection{Ograničenja pravnog prometa i izvoza kulturnih dobara $u$ hrvatskom pravu}

U Republici Hrvatskoj se predviđa da su sva kulturna dobra od interesa za Republiku Hrvatsku i uživaju njezinu osobitu zaštitu. ${ }^{88}$ Ujedno sva kulturna dobra i sva preventivno zaštićena dobra sukladno ZZOKD-u predstavljaju nacionalno blago. ${ }^{89}$ To znači da hrvatsko pravo prihvaća ekstenzivni pojam kulturnog dobra i nacionalnog blaga, tako da nije potrebna nikakva posebna veza s hrvatskim nacionalnim kontekstom da bi dobro bilo zaštićeno. ${ }^{90}$ Zbog toga je moguće da i kulturna dobra koja se nađu na teritoriju Republike Hrvatske budu zaštićena kao nacionalno blago, premda se radi o dobrima koja izvorno potječu iz drugih država. S obzirom na to da po čl. 67. st. 1 . ZZOKD-a nije dopušten trajni, vremenski neograničen izvoz i iznošenje nacionalnog

83 Detaljni pregled međunarodnih instrumenata za zaštitu kulturnih dobara i komparativnih nacionalnih rješenja u 15 zemalja vidi u Toshiyuki K. (ed.), The Impact of Uniform Laws on the Protection of Cultural Heritage and the Preservation of Cultural Heritage in the $21^{\text {st }}$ century, Leide, Boston, Martinus Nijhoff Publishers, 2010. te u istom djelu rad o hrvatskom pravnom okviru u ovom području od Gliha, I.; Josipović, T., Croatian National Legal Framework - The Impact of Uniform Laws on the Protection of Cultural Heritage and the Preservation of Cultural Heritage, str. 247-280.

84 Studija, str. 166.

85 Javna rasprava 2016, str. 6.

86 Studija, str. 197-199.

87 Studija, str. 190.

88 Čl. 2. st. 1. Zakona o zaštiti i očuvanju kulturnih dobara, NN br. 69/99, 151/03, 157/03, 100/04, 87/09, 88/10, 61/11, 25/12, 136/12, 157/13, 152/14 , 98/15. Dalje kao: ZZOKD.

89 Čl. 2. st. 2. ZZOKD.

90 Ovo proizlazi i iz same definicije kulturnog dobra u čl. 2. st. 3. ZZOKD-a po kojem su to sve pokretne i nepokretne stvari od umjetničkoga, povijesnoga, paleontološkoga, arheološkoga, antropološkog i znanstvenog značenja, arheološka nalazišta i arheološke zone, krajolici i njihovi dijelovi koji svjedoče o čovjekovoj prisutnosti u prostoru, a imaju umjetničku, povijesnu i antropološku vrijednost, nematerijalni oblici i pojave čovjekova duhovnog stvaralaštva u prošlosti kao i dokumentacija i bibliografska baština i zgrade, odnosno prostori u kojima se trajno čuvaju ili izlažu kulturna dobra i dokumentacija o njima. 
blaga iz Republike Hrvatske, pri čemu se pod izvozom kulturnih dobara iz Republike Hrvatske podrazumijeva izvoz u treće zemlje izvan carinskog područja EU-a, a pod iznošenjem kulturnih dobara iz Republike Hrvatske podrazumijeva se iznošenje u države članice EU-a, očito je da je hrvatsko pravo iskoristilo mogućnosti iz čl. 36. UFEU-a o opravdanim ograničenjima prometa između država članica. Štoviše, sukladno čl. 319. Kaznenog zakona ${ }^{91}$ tko bez odobrenja nadležnog tijela trajno izveze ili iznese iz Republike Hrvatske kulturno dobro ili ga ne vrati u Republiku Hrvatsku u roku određenom odobrenjem, čini kazneno djelo oštećenja i nedozvoljenog izvoza kulturnog dobra. Takav režim u svjetlu borbe protiv terorizma čini da se Republiku Hrvatsku pozicionira kao zemlju koja nije osobito pogodna za krijumčarenje te time doprinosi toj borbi. ${ }^{92}$

Premda hrvatska kulturna dobra mogu biti i u privatnom i u javnom vlasništvu, ZZOKD predviđa u velikom broju slučajeva presumpcije u korist javnog vlasništva. Kao prvo, vlasnik koji privremeno napusti posjed kulturnog dobra, i time nastane neposredna opasnost od njegova oštećenja ili uništenja, izložen je mjeri privremenog skrbništva nad njegovim kulturnim dobrom, ${ }^{93}$ a trajnim napuštanjem on gubi vlasništvo koje stječe Republika Hrvatska. ${ }^{94}$ Kao drugo, napušteno dobro za koje se predmnijeva da ima svojstva kulturnoga dobra, a nalazi se ili se nađe u zemlji, moru ili vodi, vlasništvo je Republike Hrvatske po samome zakonu. ${ }^{95}$ Kao treće, stjecanje vlasništva ograničeno je pravom prvokupa za korist jedinica lokalne i regionalne samouprave te Republike ${ }^{96}$ koje je sankcionirano vremenski ograničenom mogućnošću poništaja. ${ }^{97}$ Ne uzimajući u obzir posebno i mogućnost izvlaštenja kulturnog dobra, ${ }^{98}$ navedena pravila bitno povećavaju vjerojatnost da kulturno dobro u konačnici dospije u vlasništvo Republike Hrvatske ili druge javnopravne osobe.

S druge strane, međutim, ZZOKD ne propisuje da je kulturno dobro neotuđivo iz javnog vlasništva, premda bi se i u tom slučaju primjenjivale odredbe o pravu prvokupa za korist ostalih ovlaštenika, osim aktualnog javnopravnog vlasnika. Radi zaštite kulturnih dobara bilo bi oportuno propisati načelo neotuđivosti, pogotovo zbog toga jer bi se time spriječila mogućnost stjecanja vlasništva po drugim osnovama, kao što je to dosjelost, odnosno stjecanje od nevlasnika.

Potonji problemi nalaze se u središtu privatnopravnog aspekta problematike zaštite kulturnih dobara. Pokretna kulturna dobra imaju pravni status pokretnina u

91 NN, br. 125/11, 144/12, 56/15, 61/15.

92 Privremeni izvoz i iznošenje su dopušteni, radi izlaganja, ekspertiza, obavljanja radova na zaštiti i očuvanju kulturnog dobra ili drugih opravdanih razloga uz odobrenje nadležnog tijela (čl. 68. st. 1. ZZOKD).

93 V. čl. 32. st. 1. ZZOKD.

94 Čl. 18. st. 2. i 32. st. 3. ZZOKD.

95 Čl. 19. st. 1. ZZOKD.

96 Ova se pravila primjenjuju i kad se radi o aukcijskoj prodaji (čl. 37a. ZZOKD) i ovršnoj prodaji (čl. 38. ZZOKD).

97 V. čl. 37. ZZOKD. Ako vlasnik proda kulturno dobro protivno pravu prvokupa, njegov nositelj može podnijeti tužbu sudu za poništenje ugovora o kupoprodaji u roku od 90 dana od dana saznanja da je sklopljen ugovor o kupoprodaji, ali najkasnije u roku od pet godina od dana sklapanja ugovora. (čl. 39. st. 1. i 2. ZZOKD).

98 V. čl. 41. ZZOKD. 
pravnom prometu (in commercio) i na njih se primjenjuje opći stvarnopravni režim stjecanja vlasništva. To uključuje u prvom redu pravila o stjecanju od nevlasnika, a podredno dosjelost.

\subsubsection{Stjecanje od nevlasnika}

Pravila o stjecanju od nevlasnika omogućavaju poštenom stjecatelju da stekne vlasništvo pokretnine ako je stekao neposredan i samostalni posjed pokretne stvari na temelju naplatnoga pravnog posla sklopljenoga radi stjecanja prava vlasništva s posjednikom kojem ta stvar ne pripada ili koji nije ovlašten njome tako pravno raspolagati. ${ }^{99}$ Iznimke su predviđene za stvari koje su vlasniku ili osobi putem koje je on posjedovao bila ukradena ili ju je vlasnik izgubio, odnosno zametnuo. ${ }^{100} \mathrm{U}$ svjetlu terorističkih aktivnosti, redovito će se raditi o ukradenim ili čak izgubljenim odnosno zametnutim kulturnim dobrima, što na prvi pogled ovakvo stjecanje čini isključenim. Logika isključenja, koja se primjenjuje kod svih stvari, jest u pravno-ekonomskoj demotivaciji krađe. Međutim, ZV predviđa i dodatne dvije iznimke od ovog isključenja, vraćajući primjenu općeg režima, i to: 1) za gotov novac i vrijednosne papire na donositelja te 2) za stjecanje na javnoj dražbi. ${ }^{101}$

Posljednja navedena iznimka je najvažnija kod stjecanja kulturnih dobara od nevlasnika, budući da su upravo javne dražbe najčešće poslovno okruženje u kojem dolazi do stjecanja odnosno prometa. Ideja zaštite javne dražbe temelji se na činjenici da javnost dražbe omogućava vlasniku da sazna za činjenicu da se njegova stvar prodaje te da vindicira stvar prije dražbe odnosno da ju spriječi. S obzirom na presumpciju vlasništva Republike Hrvatske svih napuštenih kulturnih dobara, ${ }^{102}$ osobito je važno da Republika vodi računa o svim javnim dražbama na kojima se prodaju predmeti koji mogu imati svojstvo kulturnog dobra kako bi mogla intervenirati i spriječiti nepovoljne učinke čl. 118. st. 4. ZV-a.

Republika je dodatno zaštićena i prvokupom, što joj omogućava da ugovor pobija u maksimalnom objektivnom roku od pet godina od dana sklapanja ugovora, tj. dražbe. ${ }^{103}$ Uspješno pobijanje oduzima stjecanju valjani pravni temelj, koji je temeljna pretpostavka za svako stjecanje, pa i od nevlasnika. Time se putem obveznopravne zaštite prvokupa omogućava svojevrsno produljenje roka za restitutivnu zaštitu u usporedbi s klasičnim pravilima o vindikaciji, koja su ograničena samim pravilima o stjecanju trećeg.

Pored toga, treba ponovno naglasiti pravila o poštenju stjecatelja. Stjecatelj je bio $\mathrm{u}$ dobroj vjeri ako u trenutku zaključenja posla, a ni u trenutku primanja neposrednoga

99 Čl. 118. st. 1. i 2. Zakona o vlasništvu i drugim stvarnim pravima, NN br. 91/96, 68/98, 137/99, 22/00, 73/00, 129/00, 114/01, 79/06, 141/06, 146/08, 38/09, 153/09, 143/12, 152/14. Dalje kao: ZV. U hrvatskom pravu, stjecanje od nevlasnika ima dugu povijest, koja seže još od XIV. stoljeća u statutarno pravo istarskih gradova (Poreč, Rovinj, Pula, Novigrad, Umag). V. Margetić, L., Srednjovjekovno hrvatsko pravo-Stvarna prava, Pravni fakultet u Zagrebu i Pravni fakultet u Rijeci (Zagreb, Rijeka, Čakovec), 1983., str. 38 et seq.

100 Čl. 118. st. 4. ZV.

$101 \mathrm{Id}$.

102 V. čl. 18. st. 2., čl. 32. st. 3. i čl. 19. st. 1. ZZOKD.

103 Čl. 39. ZZOKD. 
posjeda, nije znao niti je s obzirom na okolnosti imao dovoljno razloga posumnjati u to da stvar pripada otuđivatelju. ${ }^{104}$ Ova pravila imaju dvostruko djelovanje na zaštitu kulturnih dobara. S jedne strane, pravilo propisuje da čak i ako nakon dražbe stjecatelj bude obaviješten o tome da se radi o kulturnom dobru u vlasništvu Republike Hrvatske (ili trećeg), a prije nego mu je stvar predana u neposredan posjed, nema stjecanja od nevlasnika jer u konkretnom slučaju mala fides superveniens nocet. S druge strane, s obzirom na to da je prodavatelj kulturnog dobra, kao i posrednik u kupoprodaji kulturnog dobra obvezan kupcu dati na znanje da je predmet kupoprodaje kulturno dobro, predočiti dokaz o vlasništvu kulturnog dobra te predočiti isprave o odricanju od prava prvokupa, teško je za očekivati da bi se kupac koji je imao predodžbu o tome da kupuje kulturno dobro ${ }^{105}$ pored ovih zakonskih odredbi mogao smatrati poštenim. Predodžbe prodavatelja odnosno kupca bit će u pravilu vidljive iz visine kupovnine (što je, međutim, podložno relativno otegotnom dokazivanju).

Konačno, treba spomenuti i mogućnost isticanja nevaljanosti ugovora po drugim osnovama osim povrede prvokupa, pri čemu u obzir u prvom redu dolaze ništetnost zbog zabranjenosti i ništetnost zbog nedopuštene osnove. Ništetnost zbog zabranjenosti odnosi se na radnju odnosno činidbu koja je zabranjena jer je protivna Ustavu Republike Hrvatske, prisilnim propisima ili moralu društva. Ugovor je ništetan, osim ako cilj povrijeđenog pravila ne upućuje na neku drugu pravnu posljedicu ili ako zakon u određenom slučaju ne propisuje što drugo. S tim u vezi postoje dva problema. Kao prvo, hrvatsko obvezno pravo načelno ne zabranjuje prodaju tuđe stvari, jer izričito propisuje da kupoprodaja tuđe stvari obvezuje ugovaratelje. ${ }^{106}$ To znači da se za kulturna dobra u svrhu eventualne primjene mora primijeniti iznimka koja nije izričito propisana, već bi se općenito moralo pozivati na protuustavnost, ${ }^{107}$ ili nemoralnost, što nije jednostavno za prihvatiti pored činjenice da zakonodavac pri detaljnom uređenju sustava zaštite kulturnih dobara nije takvu zabranu predvidio, premda je to imao prilike učiniti. ${ }^{108} \mathrm{U}$ kontekstu antiterorističke politike EU-a, međutim, imajući u vidu da je promet kulturnim dobrima iračke i sirijske provenijencije načelno zabranjeno, postojala bi ništetnost neposredno utemeljena na europskom pravu. Ništetnost ugovora po toj osnovi u potpunosti bi onemogućavala stjecanje od nevlasnika, neovisno o poštenju stjecatelja, premda ne i dosjelost (o tome v. infra).

Kao drugo, sukladno čl. 322. st. 2. ZOO-a, ako je sklapanje određenog

104 Čl. 118. st. 3. ZV.

105 Čl. 36. st. 1. ZV.

106 Čl. 382. Zakona o obveznim odnosima, NN, br. 35/05, 41/08, 125/11, 78/15, Dalje kao: ZOO. Kupac koji nije znao niti morao znati da je stvar tuđa može, ako se zbog toga ne može ostvariti svrha ugovora, raskinuti ugovor i zahtijevati naknadu štete. Id. Pritom ZOO očito uzima u obzir pravila o stjecanju od nevlasnika i tim pravilima daje prednost, jer računa s mogućnošću da kupac ipak stekne vlasništvo, tj. da se svrha ugovora ostvari. Pravila o raskidu i naknadi štete nadovezuju se na opća pravila o evikciji, koja također dolaze do primjene samo ako do evikcije uistinu i dođe. V. čl. 432. ZOO.

107 V. npr. čl. 69. Ustava Republike Hrvatske (NN, br. 56/90, 135/97, 8/98, 113/00, 124/00, 28/01, 41/01, 55/01, 76/10, 85/10, 05/14) koji navodi da država “ štiti znanstvena, kulturna i umjetnička dobra kao duhovne narodne vrednote.)

108 Sukladno čl. 2. st. 4. Ustava, Hrvatski sabor ili narod neposredno, samostalno, u skladu s Ustavom i zakonom, odlučuje i o očuvanju prirodnog i kulturnog bogatstva i korištenju njime. 
ugovora zabranjeno samo jednoj strani, ugovor je valjan ako u zakonu nije što drugo predviđeno za određeni slučaj, a strana koja je povrijedila zakonsku zabranu snosit će odgovarajuće posljedice. Sve i kada bi se prihvatila zabrana raspolaganja na strani osobe koja zna za podrijetlo kulturnog dobra, teško bi bilo bez izričite odredbe u tom smislu, opravdati zabranu prema osobi koja za to ne zna. ${ }^{109}$ Ako ona to zna, kupac je nepošten, pa sve i kad je ugovor valjan, ne postoji mogućnost stjecanja vlasništva ne zbog nedostatka valjanog pravnog temelja, već zbog isključenja primjene pravila o stjecanju od nevlasnika, kao i (izvanredne) dosjelosti.

Slična situacija postoji i kod analize pitanja pobuda za sklapanje ugovora. Načelno pobude za sklapanje ugovora ne utječu na njegovu valjanost, ${ }^{110}$ ali ako je nedopuštena pobuda bitno utjecala na odluku jednog ugovaratelja da sklopi ugovor i ako je to drugi ugovaratelj znao ili morao znati, ugovor je ništetan. ${ }^{111} \mathrm{~S}$ obzirom na to da je nesavjesnost suugovaratelja pretpostavka ništetnosti, vidljivo je da se ona poklapa s pretpostavkom savjesnosti kod stjecanja od nevlasnika, odnosno dosjelosti. Dakle, kad postoji nesavjesnost obje ugovorne strane, ne postoji mogućnost stjecanja od nevlasnika po općim pravilima o toj vrsti stjecanja, kao niti po pravilima o izvanrednoj dosjelosti već zbog te nesavjesnosti, pa je činjenica da je ugovor ništetan iz ovog razloga od manje bitan.

Rješenja aktualna hrvatskog stvarnoga prava u bitnome su različita od ranijih rješenja po ZOVO-u. ${ }^{112}$ Sukladno čl. 30. st. 1. ZOVO-a, pošteni stjecatelj mogao je steći pravo vlasništva na temelju naplatnog posla od nevlasnika koji u okviru svoje djelatnosti stavlja u promet takve stvari, od nevlasnika kojem je vlasnik predao stvar u posjed na temelju pravnog posla koji nije osnova za pribavljanje prava vlasništva te na javnoj prodaji. ${ }^{113}$ Ove odredbe nisu branile stjecanje prava vlasništva na ukradenim, izgubljenim ili zametnutim stvarima, kao što to čini ZV, pa su one bile daleko opasnije za vlasnika kulturnog dobra od sadašnjih pravila.

S druge strane, prijašnji vlasnik mogao je ipak zahtijevati povrat stvar, ali uz naknadu po prometnoj cijeni, ako je ta stvar za njega imala posebno značenje i to $\mathrm{u}$ roku od jedne godine od stjecanja prava vlasništva. ${ }^{114}$ Imajući u vidu da kulturna dobra u pravilu imaju poseban značaj za vlasnika, kao i općenito, ova iznimka bila bi redovito primjenjiva na ukradena ili izgubljena kulturna dobra. Pravilo o naknadi, međutim, u bitnome umanjuje značaj pravila o mogućoj revindikaciji. Navedena ideja o pravu na reivindikaciju uz otkup utjecala je i na uređenje po Direktivi o povratu ukradenih i nezakonito iznesenih kulturnih dobara o kojoj se govori infra.

109 Za kupca, ZZOKD jedino propisuje da je on dužan obavijestiti nadležno tijelo na području gdje će se kupljeno kulturno dobro nalaziti (čl. 36. st. 2. ZZOKD).

110 Čl. 273. st. 1. ZOO.

111 Čl. 273. st. 2. ZOO.

112 Zakon o osnovnim vlasničkopravnim odnosima, SL SFRJ 6/1980, 36/1990, NN, br. 53/1991, 91/1996

113 Ova rješenja su odgovarala par. 367. OGZ-a o stjecanju vlasništva od nevlasnika.

114 Čl. 30. st. 3. ZOVO. Ovo pravilo djelomično je inspirirano francuskim pravom, koje u Art. 2277(1) propisuje dužnost isplate kupovnine osobi koja je ukradenu ili izgubljenu stvar stekla na javnoj prodaji ili od osobe koja se profesionalno bavi prodajom takvih ili sličnih stvari. 


\subsubsection{Dosjelost}

Dosjelost kao institut stvarnog prava rješava problem dugotrajnog raskoraka između faktičnog i pravnog stanja, tako da faktičnu vlast nakon određenog perioda pretvara u pravnu vlast. Kod pokretnina duljina tog perioda ovisi o kvaliteti posjedovanja, kao i kategoriji vlasnika protiv kojeg se dosjeda. Kod redovite dosjelosti, publicijanski (uzukapioni) posjednik pokretnina stječe vlasništvo u pravilu nakon tri godine samostalnog posjedovanja. ${ }^{115} \mathrm{U}$ ovim slučajevima dosjelost rješava i problem vlasništva na ukradenim i izgubljenim stvarima, dokidajući vlasništvo vlasnika kojemu je stvar ukradena ili izgubljena, čak i onda kada nisu ispunjene pretpostavke za stjecanje vlasništva od nevlasnika. To će biti slučaj kada je stvar prodana poštenom stjecatelju, koji nije stjecao na javnoj dražbi. Ako je stjecatelj nepošten, dosjelost je isključena, jer je poštenje pretpostavka za svaku dosjelost. ${ }^{116}$

Kad se radi o stvarima u vlasništvu Republike Hrvatske, županija i jedinica lokalne samouprave i jedinica područne (regionalne) samouprave i s njima izjednačenih pravnih osoba, kao i stvari u vlasništvu crkve ili drugih pravnih osoba koje ne traže za sebe dobitak nego služe za dobrotvorne ili druge općekorisne svrhe rok je dulji i iznosi kod redovite dosjelosti šest godina. Kako kulturna dobra nisu uvijek u javnom vlasništvu, ovaj rok će naizgled biti primjenjiv u ograničenom broju slučajeva. Međutim, iznimka bi pokrivala kulturna dobra u vlasništvu muzeja, ${ }^{117}$ a nesporno i crkvena kulturna dobra, što u velikoj mjeri proširuje krug ovako zaštićenih kulturnih dobara.

Izvanredna dosjelost primjenjuje se iznimno, kad pošteni posjednik nema valjani pravni temelj posjedovanja. S obzirom na to da je neposredni stjecatelj ukradena kulturnog dobra uvijek nepošten, izvanredna dosjelost nije primjenjiva $u$ tim slučajevima. Kasniji stjecatelji u pravilu imaju valjani pravni temelj stjecanja, što im omogućava primjenu redovite dosjelosti, pa je izvanredna dosjelost ograničena na slučajeve u kojima postoji određeni defekt u pravnom poslu koji je posljedica nekog općeg razloga nevaljanosti. Kao što je već spomenuto ranije, takvi su slučajevi rijetki prema pozitivnom pravu. Važna iznimka, međutim, postoji upravo u pogledu kulturnih dobara iračke odnosno sirijske provenijencije, gdje bi izvanredna dosjelost došla u obzir zbog zabranjenosti pravnih poslova njihovog prometa. U ovim slučajevima također se traži poštenje stjecatelja, što je po prirodi stvari relativno teško dokazati u kontekstu suvremenih zbivanja.

\subsubsection{Povrat ukradenih i nezakonito iznesenih kulturnih dobara}

Pravni okvir za povrat kulturnih dobara koja su nezakonito odnesena s teritorija države članice na teritorij druge države članice počeo se razvijati 1993. usvajanjem

115 Čl. 159. st. 2. ZV.

116 Čl. 159. st. 3. ZV.

117 Muzejska djelatnost je od interesa za Republiku Hrvatsku i obavlja se kao javna služba (čl. 1. st. 2. Zakona o muzejima, NN, br. 110/15). Kulturna dobra koja nisu u vlasništvu muzeja, već su samo u njegovom nesamostalnom posjedu (za potrebe izložbe) pa budu naknadno ukradena ne bi bila zaštićena po ovoj odredbi. 
Direktive o povratu kulturnih dobara. ${ }^{118}$ Postupak predviđen Direktivom 93/7/EEZ bio je prvi korak u uspostavi suradnje između država članica u području povrata kulturnih dobara u kontekstu unutarnjeg tržišta, radi uzajamnog priznavanja mjerodavnih nacionalnih zakona. Cilj je Direktive bio omogućiti povrat kulturnih dobara nezakonito odnesenih s područja države članice na dan 1. siječnja 1993. ili nakon toga, ${ }^{119}$ a koja je pojedina država članica prije ili nakon nezakonitog odnošenja klasificirala kao nacionalno blago umjetničke, povijesne ili arheološke vrijednosti. ${ }^{120}$ Direktivom je uređen postupak povrata kulturnog dobra od posjednika kulturnog dobra te plaćanje naknade poštenom posjedniku u slučaju oduzimanja kulturnog dobra. ${ }^{121}$

Direktiva iz 1993. zamijenjena je novom Direktivom 2014/60/EU 19. prosinca 2015. koja ju je ukinula, preuzela i u određenim aspektima izmijenila. ${ }^{122}$ Izvorno je ona ograničavala pojam „kulturno dobro” na predmet koji je prije ili nakon nezakonitog odnošenja s državnog područja države članice bio zaštićen kao nacionalno blago koje ima umjetničku, povijesnu ili arheološku vrijednost prema nacionalnom zakonodavstvu ili upravnim postupcima u smislu članka 36. UFEU-a, te koji je pripadao u jednu od kategorija predmeta navedenih u Prilogu, ${ }^{123}$ ili nije pripadao, ali je činio sastavni dio javnih zbirki navedenih u inventarima zbirki muzeja, arhiva ili knjižnica ili crkvenih inventara. ${ }^{124}$ Ograničeno polje primjene Direktive i kratki rokovi za pokretanje postupka povrata doveli su do njene rijetke primjene u državama članicama. ${ }^{125}$ Stoga je Direktivom iz 2014. prošireno polje primjene na svaki kulturno dobro koje je država članica, u okviru nacionalnog zakonodavstva ili administrativnih

118 Direktiva Vijeća br. 93/7/EEZ o povratu kulturnih dobara nezakonito odnesenih s područja države članice, SL EZ L 74, 27.3.1993., str. 74.

119 Čl. 13. Direktive 93/7/EEZ.

120 Čl. 1. st. 1. Direktive 93/7/EEZ.

121 Čl. 7-11. Direktive 93/7/EEZ.

122 Direktiva 2014/60/EU Europskog parlamenta i Vijeća od 15. svibnja 2014. o povratu kulturnih predmeta nezakonito iznesenih s državnog područja države članice i o izmjeni Uredbe (EU) br. 1024/2012 (preinaka), SL EU L 159, 28.5.2014., str. 1.; Ispravak Direktive 2014/60/EU Europskog parlamenta i Vijeća od 15. svibnja 2014. o povratu kulturnih predmeta nezakonito iznesenih s državnog područja države članice i o izmjeni Uredbe (EU) br. 1024/2012 (SL EUL 159 od 28. svibnja 2014.), SL EU L 147, 12.6.2015, str. 24. Sukladno čl. 17. st. 1. Direktive, države članice Komisiji moraju podnijeti izvješće o primjeni ove direktive do 18. prosinca 2020. i nakon toga svakih pet godina.

123 Prema Prilogu, kulturna dobra, da bi mogla biti predmetom povrata po Direktivi 93/7/EEZ, morala su biti određene starosti i/ili pripadati nekoj umjetničkoj kategoriji (knjige, mozaici, fotografije, slike, arhivska građa etc.). Pored toga, vrijednost tih dobara morala je biti jednaka ili prelaziti određenu graničnu novčanu svotu. Pritom se ocjena o tomu jesu li uvjeti u vezi s financijskom vrijednosti ispunjeni ili ne davala prilikom traženja povrata. Novčana vrijednost je bila vrijednost predmeta u državi članici od koje se traži povrat. Takvim pristupom EU je u biti ograničio zaštitu kulturnih dobara u unutarnjem prometu na umjetnički i ekonomski „vrjednija” djela što je blisko tzv. funkcionalističkom pristupu u zaštiti kulturnih dobara. V. Müller, M. M., op. cit., str. 397, 404-405.

124 Čl. 1. st. 1. Direktive 93/7/EEZ.

125 Izvješće Komisije Europskom parlamentu, Vijeću i Europskom gospodarskom i socijalnom odboru: Četvrto izvješće o primjeni Direktiva Vijeća br. 93/7/EEZ o povratu kulturnih dobara nezakonito odnesenih s područja države članice (tekst od značenja za EGP), 2008.-2011., 30. svibnja 2013., COM(2013) 310 final, str. 7. 
postupaka, kategorizirala ili definirala kao nacionalno blago koje ima umjetničku, povijesnu ili arheološku vrijednost u smislu članka 36. UFEU-a. ${ }^{126} \mathrm{U}$ tu svrhu središnje vlasti koje su u državama članicama zadužene za implementaciju Direktive morat će surađivati i izmjenjivati informacije o nezakonito uklonjenim kulturnim dobrima uz pomoć Informacijskog sustava unutarnjeg tržišta (the Internal Market Information System - IMI). ${ }^{127}$

U odnosu na Direktivu 93/7/EEZ uvedene su još neke izmjene. Tako se postupak povrata mora pokrenuti najkasnije u roku od tri godine nakon što je središnje tijelo države povrata saznalo za mjesto predmeta i osobu posjednika. ${ }^{128}$ Prema čl. 7. Direktive 93/7/EEZ subjektivni rok je iznosio godinu dana. Pored navedenog, posjednik kulturnog dobra mora dokazati da je postupao s dužnom pažnjom kada je stjecao kulturno dobro kao pretpostavku za dobivanje naknade jednom kada se naloži povrat dobra. ${ }^{129}$ Prema čl. 9. st. 2. Direktive 93/7/EEZ teret dokazivanja određivao se primjenom propisa države članice od koje se traži povrat.

Direktiva se ne odnosi neposredno na ukradena kulturna dobra, nego na nezakonito izvezena kulturna dobra. Premda se radi o dva različita kriterija, redovito je kriterij nezakonitog izvoza širi. Na primjer, kako je po hrvatskom ZZOKD zabranjen trajni izvoz i iznošenje iz RH, jasno je da su time obuhvaćena i ukradena kulturna dobra, kao i ona koja sam vlasnik nezakonito izveze.

Direktiva je implementirana u hrvatskom ZZOKD-u. Svaka država članica EU-a koja je zatražila povrat nezakonito iznesenog kulturnog predmeta može pred nadležnim sudom u Republici Hrvatskoj pokrenuti postupak protiv samostalnog posjednika ili, ako to nije moguće, protiv nesamostalnog posjednika, radi osiguravanja povrata kulturnog predmeta koji je bio nezakonito iznesen s njezina državnog područja. ${ }^{130}$

Ovakvom tužbom država članica traži fizičku predaju kulturnog dobra u njezin posjed. Premda se pri rješavanju pitanja povrata ne ulazi u pitanje vlasništva, ${ }^{131}$ nesporno je da povrat utječe na vlasništvo, zbog toga jer je po povratu mjerodavno pravo za vlasništvo pravo države u koju je dobro vraćeno. ${ }^{132}$ Literatura je upozorila

126 Čl. 2. st. 1. Direktive 2014/60/EU. Kulturni predmeti koji su kategorizirani ili definirani kao nacionalno blago ne moraju više pripadati kategorijama ili poštovati pragove povezane $s$ njihovom starošću i/ili novčanom vrijednošću kako bi mogli biti predmetom povrata u okviru ove direktive.

127 Čl. 5. st. 2. Direktive 2014/60/EU.

128 Čl. 8. st. 1. Direktive 2014/60/EU.

129 Čl. 10. st. 1. Direktive 2014/60/EU.

130 Čl. 70b. ZZOKD.

131 Ovo je izričito propisano u toč. 8. Preambule Direktive 2014/60/EU.

132 Čl. 12. Direktive 93/7/EEZ. Stamatoudi smatra da Direktiva 93/7/EEZ ne ukazuje jasno treba li pod pravom države povrata razumjeti njezino materijalno ili kolizijsko pravo. Stamatoudi, I. A., op. cit., str. 151. Za shvaćanje da upućivanje na pravo države povrata uključuje, pored domaćeg stvarnog prava, i primjenu nacionalnog kolizijskog prava v. Sajko, K., Nacionalna i međunarodna zaštita kulturnih predmeta s posebnim osvrtom na UNIDROIT Konvenciju o ukradenim ili nezakonito izvezenim kulturnim dobrima od 24. lipnja 1995, Rijeka, ZPFR, vol. 19, Suppl., 1998, str.797-798. U ovom radu se zauzima stav kako je riječ o kolizijskom pravilu direktive koje upućuje na materijalno pravo države podrijetla. Tako Jakubowski, pišući o pitanju povrata nezakonito odnesenih kulturnih dobara u kontekstu međunarodnog privatnog prava, kaže kako bivši članak 12. Direktive (sadašnji čl. 13. Direktive 2014/60/EU) ide u prilog 
da u sustavima u kojima vrijedi načelo neotuđivosti iz državnog vlasništva, kao što je to u grčkom i talijanskom pravu ${ }^{133}$ povrat koji povlači za sobom primjenu nacionalnog prava znači prestanak eventualno stečenog vlasništva po stranom pravu, tj. promjenu ne samo posjeda nego i vlasništva. Isto bi vrijedilo i u sustavima u kojima se radi o stvari extra commercium.

Uvođenje legis originis ${ }^{134}$ pokazalo je kako je temeljni cilj Direktive bio osigurati ne samo fizički povrat $u$ državu podrijetla ${ }^{135}$ već i povrat dobra u okrilje pravnog sustava ${ }^{136} \mathrm{~s}$ kojim kulturno dobro ima ,najsmisleniju” $137 \mathrm{i}$,najbližu” 138 vezu. Time je Direktiva na razini privatnog prava potvrdila specifičnost kulturnih dobara kao robe. Ona zaslužuju stvarno-pravni statut različit od onog za „običnu robu." ${ }^{\prime 39}$

načela lex originis (pravo države podrijetla kulturnog dobra, države iz koje je dobro otuđeno) kao odstupanje od temeljnog načela kada je u pitanju spor o vlasništvu kulturnih dobara - lex situs (pravo mjesta gdje se stvar nalazi u vrijeme povrata) i napominje kako se ta direktiva ne bavi izravno pitanjem primjenjivog prava već osigurava povrat kulturnog dobra u državu iz koje je otuđen, a pitanje vlasništva rješava se po kako ističe ' domaćem pravu o kulturnoj baštini”. V. detaljnije Jakubowski, A., Return of Illicitly Trafficted Cultural Objects Pursuant to Private International Law: Current Developments, u: Vrdoljak, A. F.; Francioni F. (ur.), The Illicit Traffic of Cultural Objects in the Mediterranean, Badia Fiesolana, San Domenico di Fiesole (FI), EUI Working Papers, Academy of European Law, 9/2009, str. 137-148.

133 Josipović, op. cit. str. 134.

134 Fincham, D., How Adopting the Lex Originis Rule Can Impede the Flow of Illicit Cultural Property, Columbia Journal of Law and the Arts, vol. 32, 1/2008, str. 115. Takav zaokret može se tumačiti kao svojevrsni kompromis između dva vodeća europska pravna sustava. Prema Finchamu, u načelu kontinentalno-pravni sustav daje prednost zaštiti poštenog posjednika, dok većina anglosaksonskih sustava podupire izvornog vlasnika. ibid., str., 131.

135 Tako Biondi A., op. cit., str. 1191.

136 U rješenju po kojem se dobro mora fizički i pravno „vratiti” u državu podrijetla, neovisno o poštenju posjednika i pitanja vlasništva, odražava se načelo neotuđivosti. Ovo načelo priznaje pravo države da proglasi neko nacionalno kulturno dobro neotuđivim i zabrani njegovo odnošenje, te da traži povrat u slučaju nezakonitog odnošenja u drugu državu. Ono je izraženo u međunarodnom pravu kao neosporivo pravo države, te u nekim bilateralnim konvencijama (npr. konvencija između Švicarske i Italije iz 2006.) i nacionalnim pravima (npr. francuska pravila o neotuđivosti muzejske građe). Uvažavajući pravo države da nacionalno blago veže uz svoj teritorij, druge države u stvari priznaju primat njezinog prava. Iz privatnopravne perspektive se uvođenje lex originis umjesto lex situs čini logičnim izrazom ovog načela. V. Studija, str. 6569. Time se potvrđuje „nacionalno orijentirani” koncept zaštite kulturne baštine. O konceptu „kulturnog nacionalizma” i pravno-etičkim dilemama vezanim uz izvoz kulturnih dobara v. Merryman, J. H., Cultural Property Ethics, International Journal of Cultural Property, vol. 7, 1/1998., str. 24-26.; o teorijama kulturnog nacionalizma i internacionalizma v. Stamatoudi, I. A., op. cit., str. 19-30.

137 Fincham, D., op. cit., str. 111.

138 Ibid., str., 116.

139 EU nije harmonizirao kolizijsko pravilo za slučajeve utvrđivanja vlasništva kod zakonitog prometa. Stoga se utvrđivanje vlasništva kulturnog dobra koje je zakonito odneseno u drugu državu ravna prema kolizijskim pravilima države suda pred kojim bi se pokrenuo vlasnički spor. U ovom slučaju bi se primjena načela situsa mogla opravdati jer nema elementa nedobrovoljnog odlaska dobra iz zemlje podrijetla. Davanje primata državi podrijetla kao razlogu za primjenu lex originis ne bi bilo opravdano jer se država svojevoljno „odrekla” vlastitog kulturnog dobra, kao uostalom i bivši zakonit vlasnik. Lex originis pretpostavlja da je država podrijetla u roku zatražila povrat. U slučaju da do povrata ne dođe, dobro ostaje tamo 
Po legi rei sitae fizičkim premještajem kulturnog dobra preko granica dobro dolazi pod novi pravni poredak. Drugi poredak stjecanje vlasništva nad dobrom može vezati uz jednostav(nij)e pretpostavke za dobivanje statusa poštenog posjednika, kraće prekluzivne rokove za pokretanje postupka povrata; pružati veću zaštitu naknadnim poštenim stjecateljima, a slabiju izvornim vlasnicima i sl. To pogoduje pojavi forum shoppinga, otežava položaj izvornih vlasnika i ulijeva pravnu nesigurnost zbog veće mogućnosti promjena vlasničkog režima. Česte fizičke promjene lokacije otežavaju praćenje kulturnog dobra i povećavaju rizik oštećenja u transportu. To u konačnici slabi pokušaje zaštite kulturne baštine i povećava rizik od nezakonite trgovine. ${ }^{140}$ „Strah od nepoznanica” koje donosi primjena nekog stranog prava stimulira lokalne (poštene) kupce i (pre)prodavatelje da s povećanom pažnjom provjere podrijetlo kulturnog dobra i prethodne vlasnike. ${ }^{141} \mathrm{~A}$ time i povezana mjerodavna pravila prava države podrijetla o pretpostavkama za stjecanje kulturnog dobra.

Primjena legis rei sitae stvara problem ako je dobro sastavljeno od više komplementarnih dijelova koji čine smislenu cjelinu (kolekcije knjiga, posuđa, raščlanjene antičke skulpture, izumi itd.). Ako se dijelovi zateknu u pravnom prometu u više država, umjesto jednog prava (države podrijetla) na svaki bi se dio primjenjivalo posebno pravo (države situsa). U tom slučaju primjena legis rei sitae omogućuje pojavu više vlasnika koji svaki za sebe drži dobro. To dovodi ne samo do fizičke dezintegracije dobra već i do dezintegracije kulturnog dobra kao samostalne informacijske cjeline. ${ }^{142}$ Primjena legis originis omogućava da se vlasništvo svih predmeta koji su prije odnošenja bili dio neke smislene cjeline ocijeni po jednom pravu - pravu države čijoj kulturnoj baštini ta cjelina izvorno pripada. Može se reći kako uvođenje legis originis održava filozofiju centrističkog pristupa očuvanju kulturne baštine. ${ }^{143}$ Stoga se povrat kulturnog dobra u kombinaciji s načelom legis originis može smatrati kao pretpostavka za očuvanje integriteta kulturnog konteksta. ${ }^{144}$

Najveći problem u primjeni Direktive predstavlja obveza države na isplatu naknade. Ako je naložen povrat predmeta, nadležni sud u Republici Hrvatskoj dosudit će samostalnom posjedniku pravičnu odštetu sukladno okolnostima slučaja,

gdje se nalazi i nema primjene čl. 13. Direktive, tj. određivanja vlasništva u skladu s načelom lex originis. U slučaju da država članica pokrene neki građanski ili kazneni postupak prema nacionalnom zakonodavstvu (uključujući međunarodne konvencije), pitanje vlasništva će se određivati prema kolizijskim pravilima države nadležnog suda, a to je redovito lex rei sitae.

140 Fincham, D., op. cit., str. 130.

141 Ibid., str. 149.

142 Müller, M. M., op. cit., str. 397. Npr. u podzemnim grobnicama u Aleksandriji nalaze se zanimljive antičke skulpture lokalne obitelji. Glave skulptura jasno ukazuju na njihovo europsko (grčko) podrijetlo, dok donji dio skulpture ukazuje na egipatski stil odijevanja. U slučaju odnošenja, svaki dio sam za sebe ništa ne govori o vremenu, socijalnom i kulturnom miljeu u kojem je obitelj živjela, a kulturno dobro nastalo. Tek kao integralna cjelina daju potpunu informaciju o tome da se zapravo radi o helenističkoj obitelji starog Egipta koja je, europskom podrijetlu unatoč, njegovala egipatske običaje.

143 Engl. object-centrism. Filozofija centrizma stavlja kulturno dobro i njegovu zaštitu kao takve u središte pažnje, kao vrijednost za sebe, neovisno od njegove umjetničke, socijalne, ekonomske i sl. vrijednosti i uloge. ibid., str., 395-396.

144 Tako Stamatoudi, op. cit., str. 227. 
pod uvjetom da samostalni posjednik dokaže da je pri stjecanju predmeta postupao s dužnom pažnjom. ${ }^{145}$ Ovo rješenje invocira obeštećenje poštenog stjecatelja, premda se ne radi o poštenom stjecatelju, već o poštenom samostalnom posjedniku koji možda nije stekao vlasništvo.

To je iznimno problematično rješenje zbog toga jer obveza države na isplatu postoji prema osobi koja ne mora nužno imati nikakvo pravo koje bi time bilo povrijeđeno. Plaćanje "odštete" opravdano je ako je došlo do povrede nečijeg prava kao što je to tipično kod izvlaštenja. Nejasno je ima li kriterij "pravičnosti" koji se ovdje ima primijeniti takav smisao da će sud dosuditi manju naknadu osobi koja je nije stekla vlasništvo u odnosu na osobu koja jest. Svakako "pravična" naknada se razlikuje od "tržišne" naknade, što podrazumijeva da se ne radi o kriteriju tržišne naknade koji se inače primjenjuje kod izvlaštenja, pa bi se činilo da su i kriteriji pri ocjeni visine naknade utemeljeni na "pravičnosti". Problem je u tomu što se potpuno istim pravilima obuhvaćaju i vlasnici za koje postupak znači izvlaštenje i osobe koje to nisu. Takva relativizacija vlasništva je iznenađujuća, pogotovo kraj činjenice da sve članice EU-a imaju zajedničku tradiciju zaštite vlasništva ne samo kao imovinskog, već i ljudskog prava.

Sudovi koji određuju vraćanje zbog toga su u okvirima određivanja naknade prisiljeni ulaziti u vlasničkopravna pitanja. Pri procjeni je li samostalni posjednik postupao s dužnom pažnjom u obzir se uzimaju sve okolnosti stjecanja, a posebno dokumentacija o podrijetlu predmeta, dozvole za iznošenje koje su potrebne prema pravu države članice EU-a koja je zatražila povrat, svojstva stranaka, plaćena cijena, pitanje je li samostalni posjednik izvršio uvid u bilo koji dostupan registar ukradenih kulturnih predmeta i bilo koje relevantne informacije koje je objektivno mogao pribaviti ili poduzeo bilo koji drugi korak koji bi u tim okolnostima poduzela razumna osoba. ${ }^{146}$ Teret dokaza leži na tuženiku, a ne na tužitelju, tj. poštenje se ne presumira.

Ovi kriteriji vrlo su slični onima koji bi se primjenjivali kada bi se ispitivalo poštenje kod stjecanja vlasništva od nevlasnika ili na temelju dosjelosti. S obzirom na to da su sudovi koji odlučuju o povratu sudovi države u kojoj se dobro nalazi, čini se da ovi sudovi primjenjuju svoje nacionalno pravo pri ocjeni poštenja, a ne legem originis. Time smo ponovno došli do pitanja primjene legis rei sitae, koje se sada primjenjuje, ali u jednom drugom kontekstu. Primjena legis rei sitae znači da će osoba koja je po pravu svoje države stekla vlasništvo od nevlasnika, jer to po tom pravu dopušteno, imati beneficirani položaj u odnosu na situaciju kada bi se primjenjivalo lex originis, premda je nakon vraćanja upravo lex originis mjerodavno za pitanje vlasništva. Takav dvostruki standard - jedan za pitanje naknade, a drugi za pitanje vlasništva, dovodi do toga da se prihvaća lex rei sitae, na trošak države koja traži vraćanje. Takav postupak sliči na svojevrsno institucionalizirano prekogranično izvlaštenje, premda to nije. Ako je, npr. kulturno dobro nezakonito izneseno iz Hrvatske u Italiju, pa po talijanskom pravu dođe do stjecanja od nevlasnika ${ }^{147}$ premda po hrvatskom pravu to ne bi bio

145 Čl. 70d. st. 1. ZZOKD.

146 Čl. 70d. st. 2. ZZOKD. Ova formulacija odgovara čl. 4(4) UNIDROIT konvencije.

147 Čl. 1153. tal. Codice civile, knjiga III, poglavlje VIII, GU n.79 od 4. travnja 1942 predviđa ekstremnu varijantu mogućnosti beziznimnog stjecanja poštenog stjecatelja od nevlasnika predajom u posjed. 
slučaj, talijanski sud bi primjenjujući talijansko pravo obvezao Hrvatsku na plaćanje pravične naknade poštenom stjecatelju ukradenog kulturnog dobra. S obzirom na to da je stjecatelj stekao vlasništvo, za očekivati je da bi talijanski sud dosudio naknadu koja korespondira tržišnoj. Da je primijenio hrvatsko pravo, naknada bi bila u svakom slučaju niža. Nakon povrata, za vlasništvo mjerodavno je hrvatsko pravo, što znači da je vlasnik i dalje osoba kojoj je kulturno dobro ukradeno, a ne Republika Hrvatska, koja je već platila tržišnu naknadu. To se čini osobito otegotnim za Republiku Hrvatsku, koja u konačnici snosi trošak krađe. ${ }^{148}$ Plaćanje pravične odštete ne dovodi u pitanje pravo države članice EU-a koja je zatražila povrat da poduzme korake radi naplate tih iznosa od osoba koje su odgovorne za nezakonito iznošenje kulturnog predmeta s njezina državnog područja. ${ }^{149}$ No, ovo pitanje regresnog prava često je praktično iluzorno, zbog poteškoća u pronalaženju počinitelja, kao i samih sredstava.

Postupak povrata može se pokrenuti u roku od tri godine od kada je nadležno središnje tijelo države članice EU-a koja je zatražila povrat saznalo za mjesto na kojemu se kulturni premet nalazi i za identitet njegova samostalnog posjednika ili nesamostalnog posjednika, a najdulje u roku od 30 godina od kada je kulturni predmet nezakonito iznesen iz državnog područja države članice koja je zatražila povrat. ${ }^{150} \mathrm{U}$ slučaju predmeta koji su dio javnih zbirki i predmeta koji su dio inventara crkvenih ili drugih vjerskih institucija u državama članicama EU-a u kojima oni podliježu posebnim aranžmanima za zaštitu u okviru nacionalnog prava, rok za postupak povrata je 75 godina, osim za one države članice u kojima postupak ne podliježe zastari ili u slučaju dvostranih sporazuma između Republike Hrvatske i drugih država članica EU-a kojima se predviđa rok koji premašuje 75 godina. ${ }^{151}$

Konačno, treba ukazati da opisani režim povrata uvelike odgovara pravilima već spomenute UNIDROIT konvencije. Sama ratifikacija UNIDROIT konvencije u državi članici ne isključuje primjenu Direktive 2014/60 u slučaju kretanja kulturnih dobara iz države članice u državu članicu. Naime, čl. 13. st. 3. propisuje da svojim međusobnim odnosima države ugovornice, koje su članovi organizacija gospodarskog udruživanja ili regionalnih tijela mogu izjaviti da će primjenjivati unutarnja pravila tih organizacija ili tijela pa stoga među sobom neće primjenjivati odredbe ove Konvencije, opseg koje primjene se preklapa s opsegom primjene tih pravila. S obzirom na to da je EU jedna od gospodarskih integracija i ima regionalni predznak, ovaj bi stavak imao neposrednu primjenu u odnosima između država članica EU-a. ${ }^{152}$

148 Kada bi se primijenilo talijansko pravo u potpunosti, tada bi se posljedice plaćanja pravične naknade mogle izjednačiti s izvlaštenjem, pa bi u konačnici Republika Hrvatska postala vlasnikom vraćenog kulturnog dobra. S druge strane, ako bi se primijenilo hrvatsko pravo u cijelosti, tada bi Republika Hrvatska bila dužna platiti značajno nižu naknadu, ali ne bi bila postala vlasnicom kulturnog dobra nakon povrata.

149 Čl. 70. st. 6. ZZOKD.

150 Čl. 70b. st. 3. ZZOKD.

151 Čl. 70b. st. 4. ZZOKD.

152 O spomenutom odnosu Konvencije i njenog sustava zaštite i europskog sustava zaštite kulturne baštine slično i Sajko, K. op. cit., str. 803. S druge strane, čl. 16. Direktive 2014/60 ne dovodi u pitanje niti jedan građanski ili kazneni postupak koji prema nacionalnom zakonodavstvu država članica (op. a.) može pokrenuti država članica koja je zatražila povrat i/ili vlasnik ukradenog kulturnog predmeta. Stoga danas u EU imamo dva paralelna sustava - opći harmonizirani 


\section{BUDUĆI MEHANIZMI ZAŠTITE KULTURNIH DOBARA U EUROPSKOM I NACIONALNOM KONTEKSTU}

\subsection{Javnopravni aspekt}

Jačanje ovlasti carinskih službi u borbi protiv financiranja terorizma putem nezakonite trgovine kulturnim dobrima predstavlja cilj najavljene regulacije u području uvoza kulturnih dobara. Premda najavljivana kao dio šire antiterorističke agende, ova inicijativa ima širi potencijal, jer ima priliku izgraditi i upotpuniti pravni okvir kojim bi se uredio uvoz kulturnih dobara iz svih trećih zemalja, uključujući one koje nisu žarište terorizma.

Pritom nije potpuno jasno naznačena pravna osnova za usvajanje novoga zakonodavnog prijedloga o uvozu kulturnih dobara iz trećih zemalja. Sukladno čl. 167. st. 3. UFEU-a, pored usmjerenosti na promicanje vlastitih kultura, ${ }^{153} \mathrm{EU}$ i države članice podupiru suradnju s trećim državama i međunarodnim organizacijama nadležnim za područje kulture, osobito s Vijećem Europe. ${ }^{154}$ Tako stipulirana odredba uređuje institucionalnu suradnju EU-a u području kulture, a ne pitanje prometa kulturnim dobrima, a niti je uključeno usvajanje bilo uredbi bilo direktiva kao zakonodavnih akata. ${ }^{155}$

Analizirajući pravne osnove za usvajanje drugih instrumenata europskog acquisa u području prometa kulturnim dobrima - Uredbe 116/2009 (vanjski izlazni promet), Direktive 2014/60 (unutarnji promet) te uredbi 1210/2003 i 1332/2013 (ograničenja vanjskog ulaznog prometa) vidi se da su usvojene kao dio zajedničke trgovinske politike, ${ }^{156}$ kao dio pravila o usklađivanju zakonodavstva radi uspostave unutarnjeg tržišta, ${ }^{157}$ odnosno kao dio mjera ograničavanja gospodarsko-financijskih odnosa s trećim državama odnosno suzbijanja terorizma. ${ }^{158}$ Pravnu osnovu za usvajanje novoga zakonodavnog prijedloga treba tražiti u odredbama o zajedničkoj trgovinskoj politici. Budući zakonodavni prijedlog trebao bi spriječiti nezakoniti promet kulturnim dobrima neovisno o zemlji podrijetla ${ }^{159}$ te se on ne ograničava na nezakoniti promet kulturnim dobrima iz zemalja pogođenih trenutnim valom terorizma. ${ }^{160}$ Prijedlog bi

sustav po Direktivi 2014/60 i posebni međunarodnopravni sustav po UNIDROIT konvenciji.

153 V. čl. 167. st. 4. UFEU.

154 Čl. 167. st. 3. UFEU. Konkretni izraz ove politike jest supra spomenuta Zajednička komunikacija o strategiji međunarodnih kulturnih odnosa.

155 V. Studija, str. 47.

156 Prema preambuli Uredbe 116/2009, riječ je o bivšem članku 133. Ugovora o Europskoj zajednici, sadašnji čl. 206 et seq. UFEU.

157 Prema preambuli Direktive 2014/60, riječ je o čl. 114. UFEU. V. i. Studija..., str. 39.

158 Prema preambulama Uredbi 1210/2003 i 1332/2013, riječ je o članku 215. UFEU. Prema preambuli Uredbe 1210/2003, temelj za usvajanje je su bili članci 60. UEZ o suzbijanju terorizma i čl. 301. UEZ (sadašnji članak 215. UFEU).

159 Ususret Strategiji, str. 11-12; AP, str. 13

160 Za pretpostaviti je da će budući akt odrediti da je za pojam kulturnog dobra mjerodavno pravo države iz kojeg ono potječe. No ostaje nejasno hoće li buduća pravila o uvoznim certifikatima biti potrebna za sva kulturna dobra ili samo ona određene starosti i/ili vrijednosti. 
trebalo usvojiti u obliku uredbe ${ }^{161}$ kojom bi se osigurala obvezatnost, opća i izravna primjena budućih pravila o uvozu kulturnih dobara. Time bi se sveobuhvatno popunila postojeća pravna praznina i neujednačenost pri uređivanju ove materije u nacionalnim zakonodavstvima država članica.

Hrvatsko pravo već je usvojilo ideju o kontroli uvoza. Kulturna dobra mogu se uvoziti i unositi u Republiku Hrvatsku uz odobrenje zemlje iz koje se uvoze ili unose, ${ }^{162}$ a uvoznik kulturnoga dobra ili osoba koja unosi kulturno dobro, dužna je bez odgađanja prijaviti kulturno dobro nadležnom tijelu. ${ }^{163}$

$\mathrm{Na}$ obje razine ostaje pitanje je li kontrola uvoza za sva kulturna dobra najbolje rješenje za njihovu zaštitu. Premda općenito kontrola uvoza može imati dobre preventivne učinke, u kriznim situacijama kao što je to slučaj Sirije odnosno Iraka zabrana uvoza može imati negativne posljedice po sudbinu kulturnog dobra, jer dobro može biti uništeno ili napušteno. Kontrola uvoza temelji se na potvrdama koje izdaje strana država, što predstavlja značajno ograničenje hrvatske kulturne politike. Hrvatski službenici u takvim slučajevima jednostavno provode izvoznu politiku dotične države, bez preispitivanja je li takva politika u skladu s hrvatskom politikom, pa čak i s obvezama koje proizlaze za Republiku Hrvatsku u provođenju međunarodnih instrumenata zaštite kulturnih dobara. Ista situacija postoji i na supranacionalnoj, europskoj razini, s još širim posljedicama, budući da bi sve države članice EU-a primjenom takvog restriktivnog režima bile dovedene u sličnu situaciju. Slijedom toga, budući instrumenti morali bi razmisliti je li apsolutna kontrola uvoza uvijek najbolje rješenje ili takvu mjeru ipak treba prilagoditi konkretnom slučaju.

UNESCO-ova konvencija obvezuje u čl. 7(b)(i) države da zabrane uvoz kulturnih dobara ukradenih iz muzeja ili s javnog ili vjerskog spomenika ili iz kakve slične ustanove, a ne nezakonito izvezenih kulturnih dobara. Zabrana uvoza spomenuta je kao iznimna mjera po čl. 9. koji se primjenjuje kad se država članica čija je kulturna baština ugrožena zbog arheoloških ili etnoloških pljački obrati drugim državama $\mathrm{s}$ pozivom da sudjeluju u svakoj zajedničkoj međunarodnoj akciji, radi određivanja i primjene nužnih konkretnih mjera. Čak i UNIDROIT konvencija prediviđa u čl. 3. da se povrat nezakonito izvezenog kulturnog dobra može narediti samo ako se dokaže da odnošenje dobra s teritorija države tražiteljice znatno šteti fizičkom očuvanju dobra ili njegova okruženja, cjelovitosti nekog složenog dobra, očuvanju neke informacije, primjerice informacije znanstvene ili povijesne naravi, tradicionalnoj ili ritualnoj uporabi dobra u plemenskoj ili starosjedilačkoj zajednici, ili utvrdi da je dobro od iznimnog kulturnog značenja za državu tražiteljicu, a ne u svakom slučaju.

\subsection{Privatnopravni aspekt}

Iz gornje analize može se zaključiti da su opisane međunarodne aktivnosti EU-a u području borbe protiv financiranja terorizma nezakonitom trgovinom kulturnim dobrima političke prirode. Zaključci Vijeća i EP te ostale spomenute EU inicijative

161 Čl. 207. st. 2. UFEU.

162 Čl. 70. st. 1. ZZOKD.

163 Čl. 70. st. 2. ZZOKD. 
također su političke i javnopravne prirode. Postojeći režim uvoza uspostavljen Uredbama 1210/2003 i 1332/2013 javnopravni je izraz politike sankcija radi provedbe vanjske i sigurnosne politike EU-a. I najavljene mjere carinske politike kao javnopravne mjere trenutno se vide kao osnovni instrument u borbi protiv financiranja terorizma prodajom kulturne baštine, a time i kao instrument zaštite kulturne baštine. Privatnopravne mjere za sada nisu dirane. Riječ je o praznini koja svoje korijene vuče iz međunarodnog prava. UNESCO konvencija instrument je javnog prava kojem nedostaju odredbe koje bi se bavile privatnopravnim aspektima prometa kulturnim dobrima kao neodvojivim dijelom međunarodnog prometa kulturnim dobrima. ${ }^{164}$

Slična je situacija i s UNIDROIT konvencijom, ${ }^{165}$ i upravo zbog toga je čini se, došlo do nespretnosti u pogledu njezinog utjecaja na Direktivu o povratu, pa onda i u implementacijskim nacionalnim pravilima. Kao što je ranije istaknuto, pravila o povratu, upravo jer ne ulaze u pitanje vlasništva izričito, premda na njega nesporno utječu, mogu dovesti do nejasnih učinaka i otegotnog položaja države tražiteljice. Dva su pitanja ovdje ključna: prvo, pitanje određivanja naknade, i drugo, pitanja posljedica povrata. Ta dva pitanja ne mogu se promatrati razdvojeno, jer se naknada daje upravo zbog tih posljedica. Kako su posljedice različite ovisno o primjeni nacionalnog prava pojedine države tražiteljice, trebalo bi biti potpuno jasno uređeno kakav je odnos između vlasništva i naknade.

Pritom, jedan od temeljnih problema na europskoj razini ostaje činjenica da EU po čl. 345. TFEU-a nema nadležnost za uređivanje stvarnopravnih odnosa. Međutim, literatura već duže vrijeme raspravlja o pravom značenju ovakvog isključenja, i uglavnom dovodi taj zaključak u pitanje. ${ }^{166}$ Čini se da je EK i dalje o tomu podijeljena.

164 Studija, str. 245.

165 UNIDROIT konvencijom se željelo unificirati pravo zaštite kulturnog blaga (izloženog međunarodnim krađama i ilegalnom izvozu) na međunarodnoj razini i izbjeći nepredvidljivost i pravna nesigurnost koju donose nacionalna kolizijska pravila upućujući na različita nacionalna prava. Njezin cilj nije bio unificirati stvarnopravna rješenja o stjecanju kulturnog predmeta od nevlasnika (npr. stjecanje vlasništva bona fide) ili u slučajevima nelegalnog izvoza već indirektno urediti pravne posljedice tih situacija (tj. kako riješiti te situacije kada do toga dođe odnosno kako tada pomiriti interese vlasnika, kupaca u dobroj vjeri i javnopravni interes države, op. a.). Konvencija uređuje pretpostavke i način povrata, bez obzira je li i tko je po nacionalnim pravu stekao vlasništvo. Konvencija uređuje pitanje povrata ukradenih i ilegalno izvezenih predmeta putem zahtjeva koji imaju međunarodno značenje (zahtjev koji ima inozemno obilježje, bez ograničenja). Vidi pobliže o postupku donošenja ove Konvencije u Sajko, K., UNIDROIT Konvencija o ukradenim ili nezakonito izvezenim kulturnim dobrima od 24. lipnja 1995. - važan doprinos učinkovitoj međunarodnoj zaštiti kulturnih dobara, Zagreb, Pravo i porezi, vol. 9, 8/2000, str. $10-11$.

166 V. npr. Van Erp, S., From Euratom Property Law to European Union Property Law: A Concise Overview of the Development Towards a European Property Law, u: Moccia, L. (ur.), The Making of European Private Law: Why, How, What, Who, 2013., str. 149; Akkermans, B., Raemakers, E., Article 345 TFEU (ex Article 295 EC), Its Meanings and Interpretations, European Law Journal, vol. 16, 3/2010, str. 292; Caramelo-Gomes, J., Unification in the Field of Property Law from the Perspective of European Law, u: Faber W. i Lurger, B. (ur.), Rules for the transfer of Movables, a candidate for European Harmonisation or National Reform?, 2008, str. 239; Caruso, D., Private Law and Public Stakes in European Integration: the Case of Property, European Law Journal, vol. 10, 6/2004, str. 751. 
U svakom slučaju, u pogledu kulturnih dobara ne čini se toliko teško zamislivim da se nadležnost opravda nekom od drugih nadležnosti koje su i ranije korištene (v. supra). Radi sprječavanja i borbe protiv nezakonitog prometa kulturnim dobrima, autori Studije preporučili su jedinstveni standard dobre vjere, koji je unesen u novu direktivu iz 2014. ${ }^{167}$ Predloženo je i da se u odnosu na posjednika u zloj vjeri napusti prigovor zastare u pogledu tužbenih zahtjeva za povrat kulturnog dobra, odnosno prigovor dosjelosti. ${ }^{168} \mathrm{U}$ hrvatskom pravu ovog problema nema, budući da je, kao što je istaknuto supra, dobra vjera uvijek pretpostavka stjecanja.

Vezano uz utvrđivanje vlasništva, budući sustav bi trebao osim uvoznih certifikata urediti i pitanje utvrđivanja vlasništva kulturnog dobra, jer o tom pitanju uvelike ovisi njegova cjelovita privatnopravna zaštita. Njime bi trebalo propisati i postupak povrata kulturnog dobra ako bi se ono zateklo na teritoriju EU-a mimo uvoznih formalnosti, tj. uvoznih odobrenja i certifikata. Kao što je već spomenuto, treba razmisliti da buduća regulacija uvoza kulturnih dobara iz trećih zemalja predvidi ulogu muzeja u EU kao svojevrsnih privremenih repozitorija nezakonito uvezenih kulturnih dobara koje je zaplijenila carinska služba države članice EU-a, do trenutka dok se ne steknu uvjeti za povratak vlasniku odnosno nadležnim institucijama u utvrđenoj zemlji podrijetla. ${ }^{169}$

Ako kulturno dobro uđe na teritorij EU sukladno predviđenom sustavu uvoznih odobrenja, ono će se naći u zakonitom prometu na unutarnjem tržištu, i na njega će se, pod pretpostavkom da je zaštićeno pravom bilo koje države članice primjenjivati zajednička pravila o povratu iz Direktive 2014/60. Ako nije zaštićeno, kao i ako je zaštićeno, ali nije vraćeno, primjenjuju se pravila legis rei sitae. EU bi i u slučaju uvoza trebao razmisliti o uvođenju europskoga kolizijskog pravila, po uzoru na čl. 13. Direktive 2014/60, kojim bi se tradicionalni model lex situs zamijenio s lex originis. ${ }^{170}$ Prihvatom takvog modernog modela europsko bi pravo krenulo u smjeru prema spomenutom načelom (stvarne i pravne) neotuđivosti kulturnog dobra, što bi moglo imati učinke na globalnu harmonizaciju međunarodnog privatnog prava u području prometa kulturnim dobrima. ${ }^{171}$

Po nacrtu Prijedloga za Zakon o međunarodnom privatnom pravu ${ }^{172}$ predviđena je mjerodavnost legis rei sitae i prije i nakon povrata kulturnog dobra u pogledu stjecanja vlasništva. ${ }^{173}$ Ovo je izričito suprotno pravilu iz Direktive, kao i čl. 70d. ZZOKD-a. Premda je predviđeni Zakon supsidijarne naravi ${ }^{174}$ i premda je renvoi

167 V. preporuku br. 4. Studije, str. 220.

168 V. preporuku br. 5, str. 225

169 Takva se mogućnost izravno spominje u obrascu Javne rasprave, pitanje 6, str. 13.

170 Slično Preporuka br. 19. Studije, str. 226, koja međutim predlaže rješenje kakvo poznaje belgijsko kolizijsko pravo. Po čl. 90. belgijskog Zakona o međunarodnom privatnom pravu od 16. srpnja 2004. (Moniteur belge, 27. srpanj 2004., str. 57344) država, koja traži povrat, može birati između vlastitog prava (lex rei originis) i prava države na čijem se području dobro zatekne u trenutku tužbe (lex rei sitae), s tim da se i pošteni stjecatelj može pozivati na lex rei sitae (čime se ova odredba znatno oslabljuje). V. i npr. u engleskoj sudskoj praksi, Republic of Iran v. Barakat Galleries [2007] EWCA Civ 1374 (koja prihvaća lex originis).

171 Tako u kontekstu trgovine kulturnim dobrima općenito i Fincham, D., op. cit., str. 149.

172 V. https://esavjetovanja.gov.hr/Econ/MainScreen?EntityId=4310, 18. siječnja 2017.

173 Ibid., čl. 20-21.

174 Ibid., čl. 2. 
isključen, ${ }^{175}$ možda bi bilo korisno iznimku predvidjeti i u tom Zakonu, kad se već pristupilo izradi novog propisa. Eventualne druge značajne promjene trebalo bi razmotriti u kontekstu razvoja europskog prava.

Hrvatsko stvarno pravo i dalje ne razlikuje u svojim općim institutima pravila koja se primjenjuju na kulturna dobra i na sve ostale stvari. Zbog toga bi trebalo razmotriti prilagodbu ovih pravila suvremenim okolnostima. To se u prvom redu odnosi na pravila o stjecanju od nevlasnika, koja ne isključuju stjecanje od nevlasnika ukradenih kulturnih dobara na javnoj dražbi, kao niti dosjelošću. Rokovi dosjelosti postavljeni su relativno kratko, u svakom slučaju kraće od rokova za povrat prema pravilima iz ZZOKD. Pored toga, pravila o dosjedanju državnog vlasništva mogla bi se isključiti ako bi se režim javnih dobara, barem u tom segmentu, pretvorio $u$ režim općih dobara. S obzirom na to da uprava ostaje Republici Hrvatskoj ${ }^{176}$ prava promjena bila bi upravo u segmentu prometa, odnosno stjecanja vlasništva, koji je ionako zabranjen po čl. 2. i 3. UNESCO konvencije.

\section{ZAKLJUČAK}

Provedena analiza ukazuje da se na svim planovima, i na međunarodnom, i na europskom, i na nacionalnom, zaštita kulturnih dobara kreće u smjeru podizanja stupnja zaštite. Ovo je danas postalo posebno važno pitanje ne samo zbog zaštite kulturnih dobara, već zbog zaštite ljudi. Taj kontekst upravo je posljedica poveznice nezakonitog izvoza, krijumčarenja i prodaje bliskoistočnih kulturnih dobara i financiranja terorizma. Zaštitom kulturnih dobara i na europskoj i na nacionalnoj razini, istovremeno sudjelujemo u svjetskoj borbi za zaštitu baštine čovječanstva $i$ zaštite od terorizma, oduzimajući odnosno sprječavajući korištenje kulturnih dobara za financiranje zločina. Aktualne napore EU-a treba svakako pohvaliti, i one koji se tiču nedavnih promjena u režimu zaštite kulturnih dobara donošenjem nove Direktive iz 2014. i one koji se sastoje u donošenju izmjena uvoznog režima. Treba istaknuti da takvo djelovanje neće biti dostatno ako se privatnopravni mehanizmi, konkretno oni iz područja stvarnog prava, ne aktiviraju na daleko većoj razini od postojeće i u ključnim pitanjima ne postigne konsenzus. Premda je inicijativa EU-a ovdje dobrodošla, ne treba zaboraviti da nacionalni zakonodavci imaju slobodu djelovanja i bez posebnog poticaja ili upute EU-a, a s obzirom na zajedničke vrijednosti $\mathrm{u}$ području zaštite kulturnih dobara. Konačno, sada već izvjesnost britanskog napuštanja EU-a ostavit će očekivano države članice bez tako velikih nacionalnih razlika u pogledu stjecanja vlasništva od nevlasnika, što bi moglo izvršiti dodatni pritisak na nacionalne zakonodavce da odstupe od tradicionalnih pravila koja, i dalje, pogoduju krijumčarenju.

\section{LITERATURA}

1. Akkermans, B., Raemakers, E., Article 345 TFEU (ex Article 295 EC), Its Meanings and Interpretations, European Law Journal, vol. 16, 3/2010, str. 292

175 Ibid., čl. 9.

176 V. čl. 3. st. 3. i čl. 35. st. 4. ZV. 
2. Biondi, A., The Merchant, the Thief \& the Citizen: the Circulation of Works of Art within the European Union, Common Market Law Review, vol. 34, 5/1997, str. 1181

3. Blake, J., On Defining the Cultural Heritage, International and Comparative Law Quarterly, vol. 49, 1/2000, str. 61-85

4. Bradamante, V., Zaštita kulturne baštine po nacionalnom i međunarodnom pravu s posebnim osvrtom na hrvatsku kulturnu baštinu stradalu tijekom rata 1991.-1995., Zagreb, Pravnik,, vol. 37, 1 /2003, str. 79-80

5. Caramelo-Gomes, J., Unification in the Field of Property Law from the Perspective of European Law, u: Faber W. i Lurger, B. (ur.), Rules for the transfer of Movables, a candidate for European Harmonisation or National Reform?, 2008, str. 239

6. Caruso, D., Private Law and Public Stakes in European Integration: the Case of Property, European Law Journal, vol. 10, 6/2004, str. 751

7. Casini, L., "Italian Hours": The globalization of cultural property law, International Journal of Constitutional Law, vol. 9, 2/2011, str. 369-393

8. Fincham, D., How Adopting the Lex Originis Rule Can Impede the Flow of Illicit Cultural Property, Columbia Journal of Law and the Arts, vol. 32, 1/2008, str. 115

9. Gliha, I.; Josipović, T., Croatian National Legal Framework - The Impact of Uniform Laws on the Protection of Cultural Heritage and the Preservation of Cultural Heritage, str. $247-280$

10. Gonzalez, M. A., New Legal Tools to Curb the Illicit Traffic of Pre-Columbian Antiquities, Colum. J. Transnat'l L. vol. 12, 1973, str. 316

11. Gormley, L. W., EU Law of Free Movement of Goods and Customs Union, Oxford, Oxford University Press, 2009, str. 387

12. Groenen, A., A Passport for Cultural Goods, predavanje održano na 21st Ius Commune Congress, Maastricht University, 25. studeni 2016, dostupno na http://www.iuscommune. eu/html/activities/2016/2016-11-24/workshop_11b_Groenen.pdf., 24. studeni 2016, 31.prosinac 2016

13. Jakubowski, A., Return of Illicitly Trafficted Cultural Objects Pursuant to Private International Law: Current Developments, u: Vrdoljak, A. F.; Francioni F. (ed.), The Illicit Traffic of Cultural Objects in the Mediterranean, Badia Fiesolana, San Domenico di Fiesole (FI), EUI Working Papers, Academy of European Law, 9/2009, str. 137-148

14. Josipović, Tatjana, Zaštita kulturnih dobara u Europskoj uniji u: Gavella, N. i dr., Europsko privatno pravo, Zagreb, Pravni fakultet, 2002, str. 106

15. Lichtner-Kristić, M. Izvoz i iznošenje kulturnih dobara iz Hrvatske u kontekstu usklađivanja hrvatskog pravnog sustava sa pravnom stečevinom Europske unije, Zagreb, Carinski vjesnik, vol. 16, 5/2007, str. 52-71

16. Margetić, L., Srednjovjekovno hrvatsko pravo-Stvarna prava, Pravni fakultet u Zagrebu i Pravni fakultet u Rijeci (Zagreb, Rijeka, Čakovec), 1983.

17. McAlee, J., From the Boston Raphael to the Peruvian Pots: Limitations on the Importation of Art Into the United States, Dick. L. Rev. vol. 85., 1980, str. 565

18. Merryman, J. H., Cultural Property Ethics, International Journal of Cultural Property, vol. 7, 1/1998., str. 24-26

19. Müller, M. M., Cultural Heritage Protection: Legitimacy, Property, and Functionalism, International Journal of Cultural Property, vol. 7, 2/1998, str. 401-402

20. Oliver, P., Free Movement of Goods in the European Community: under Articles 28 to 30 of the EC Treaty, London, Sweet\&Maxwell, 2003, str. 285

21. Peters, R., The Protection of Cultural Property in EU Law: Status Quo and Future Perspectives, u: Desmarais, F. (ur.), Countering Illicit Trade in Cultural Goods, 2015., str. 146

22. Prott, L. V.; O’Keefe, P., 'Cultural Heritage' or 'Cultural Property', International Journal of Cultural Property, vol. 1, 2/1992, str. 307-308

23. Sajko, K., Nacionalna i međunarodna zaštita kulturnih predmeta s posebnim osvrtom na 
UNIDROIT Konvenciju o ukradenim ili nezakonito izvezenim kulturnim dobrima od 24. lipnja 1995, Rijeka, ZPFR, vol. 19, Suppl., 1998, str.797-798

24. Sajko, K., UNIDROIT Konvencija o ukradenim ili nezakonito izvezenim kulturnim dobrima od 24. lipnja 1995. - važan doprinos učinkovitoj međunarodnoj zaštiti kulturnih dobara, Zagreb, Pravo i porezi, vol. 9, 8/2000, str. 10 -11

25. Stamatoudi, I. A., Cultural Property Law and Restitution A Commentary to International Conventions and European Union Law, Cheltenham, UK; Northampton, MA, USA, IHC series in heritage management, Edward Elgar, 2011

26. Šošić, T. M, Pojam kulturne baštine - međunarodno pravni pogled, Split, ZRPF, vol. 51, 4/2014., str. 838.

27. Toshiyuki K. (ed.), The Impact of Uniform Laws on the Protection of Cultural Heritage and the Preservation of Cultural Heritage in the $21^{\text {st }}$ century, Leide, Boston, Martinus Nijhoff Publishers, 2010.

28. Van Erp, S., From Euratom Property Law to European Union Property Law: A Concise Overview of the Development Towards a European Property Law, u: Moccia, L. (ur.), The Making of European Private Law: Why, How, What, Who, 2013., str. 149

29. Vukšić, Z., Pravni i porezni promet kulturnih dobara, Zagreb, Hrvatska pravna revija, vol. 3., 6/2003, str. 85-91

30. Willett, H. D., Ill-Goten Gains: A Response to the Islamic State's Profits from the Illicit Antiquities Market, Arizona Law Review, vol. 58, 3/2016, str. 831-865

Pravni izvori

1. Aneks Komunikaciji Komisije Europskom parlamentu i Vijeću:Akcijski plan za jačanje borbe protiv financiranja terorizma, $\operatorname{COM}(2016) 50$ final, str. 4.

2. CNRS - UMR 6224, Contract No. Home/2009/ISEC/PR/019-A2, Završno izvješće listopad 2011, str. 40, dostupno na http://www.do.etat.lu/voyages/Report_Trafficking _ in_cultural_goods_EN.pdf, 1.prosinac 2016.

3. Direktiva Vijeća br. 93/7/EEZ o povratu kulturnih dobara nezakonito odnesenih s područja države članice, SL EZ L 74, 27.3.1993., str. 74.

4. Direktiva 2014/60/EU Europskog parlamenta i Vijeća od 15. svibnja 2014. o povratu kulturnih predmeta nezakonito iznesenih s državnog područja države članice i o izmjeni Uredbe (EU) br. 1024/2012 (preinaka), SL EU L 159, 28.5.2014., str. 1.

5. Ispravak Direktive 2014/60/EU Europskog parlamenta i Vijeća od 15. svibnja 2014. o povratu kulturnih predmeta nezakonito iznesenih s državnog područja države članice i o izmjeni Uredbe (EU) br. 1024/2012 (SL EUL 159 od 28. svibnja 2014. ), SL EU L 147, 12.6.2015, str. 24.

6. Izvješće Komisije Europskom parlamentu, Vijeću i Europskom gospodarskom i socijalnom odboru o provedbi Uredbe Vijeća (EZ) br. 116/2009 od 18. prosinca 2008. o izvozu kulturnih dobara, 1. siječanj 2011.- 31. prosinac 2013., Bruxelles, 1. travanj 2015., (COM(2015) 144 final)

7. Izvješće Komisije Europskom parlamentu, Vijeću i Europskom gospodarskom i socijalnom odboru: Četvrto izvješće o primjeni Direktiva Vijeća br. 93/7/EEZ o povratu kulturnih dobara nezakonito odnesenih s područja države članice (tekst od značenja za EGP), 2008.-2011., 30. svibanj 2013., COM(2013) 310 final, str. 7

8. Komunikacija Komisije Europskom parlamentu, Vijeću, Europskom gospodarskom i socijalnom odboru i Odboru regija: Ususret cjelovitom pristupu kulturnoj baštini u Europi, Bruxelles, 22. srpanj 2014., COM(2014) 477 final

9. Komunikacija Komisije Europskom parlamentu i Vijeću o Akcijskom planu za jačanje borbe protiv financiranja terorizma, Bruxelles, 2. veljače 2016., COM (2016)50 final.

10. Rezolucija VSUN br. 2199 (2015) od 12. veljače 2015

11. Rezolucija EP br. 2015/2649(RSP)

12. Rezolucija VSUN br. 2253(2015) od 17.12.2015. 
13. Ugovor o funkcioniranju EU, pročišćena inačica, SL C 202, 7. lipnja 2016.

14. Uredba Vijeća (EEZ) br. 3911/92 od 9. prosinca 1992. o izvozu kulturnih dobara, SL EZ L 395, 31.12.1992., str. 1.

15. Uredba Vijeća (EZ) br. 116/2009 od 18. prosinca 2008. o izvozu kulturnih dobara, SL EU L 39, 10.12.2009., str. 1

16. Uredba Vijeća (EZ) br. 1210/2003 od 7. srpnja 2003. o određenim posebnim ograničenjima gospodarskih i financijskih odnosa s Irakom i stavljanju izvan snage Uredbe (EZ) br. 2465/96, SL EZ L 169, 8.7.2003., str. 6.

17. Uredba Vijeća (EU) br. $36 / 2012$ od 18. siječnja 2012. o mjerama ograničavanja s obzirom na stanje u Siriji i o stavljanju izvan snage Uredbe (EU) br. 442/2011, SL L EU 16, 19.1.2012, str. 1.

18. Uredba Vijeća (EU) br. 1332/2013 od 13. prosinca 2013. o izmjeni Uredbe (EU) br. 36/2012 o mjerama ograničavanja s obzirom na stanje u Siriji, SL L EU 335, 14.12.2013, str. 3.

19. Zajednička komunikacija Europskom parlamentu i Vijeću: Ususret Strategiji EU-a za međunarodne kulturne odnose, Bruxelles, 8. lipanj 2016., JOIN(2016) 29 final

20. Zaključci Europskog vijeća od 28. studenog 2008., 15049/1/08 REV 1 CRIMORG 175 ENFOPOL 206, 14224/2/08 REV 2 CRIMORG 166 ENFOPOL 191, dio 12

21. Zaključci Europskog vijeća od 13. i 14.11.2011., 17541/11 ENFOPOL 415 CULT 111 ENFOCUSTOM 143.

22. Zaključci Europskog vijeća od 18. prosinca 2015. EUCO 28/15, Dio drugi, t. 10.

23. Zaključci Europskog vijeća od 12. veljače 2016. EUCO 50/16, t. 12.

Web stranice

1. http://ec.europa.eu/eurostat/web/products-statistical-books/-/KS-04-15-737, 6. srpanj 2016., 1. prosinac 2016.

2. http://ec.europa.eu/culture/policy/culture-policies/trafficking_en, 6. siječanj 2017., 7. siječanj 2017.

3. https://ec.europa.eu/taxation_customs/sites/taxation/files/consultation_cultural_goods_ survey_en.pdf, 6. siječanj 2017., 7. siječanj 2017.

4. https://ec.europa.eu/taxation_customs/consultations-get-involved/customsconsultations/consultation-rules-import-cultural-goods_en. (28.12.2016.).

5. http://www.europarl.europa.eu/sides/getDoc.do?pubRef=-//EP// NONSGML+MOTION+P8-RC-2015-0375+0+DOC+PDF+V0//EN, 28. travanj 2015., 28. prosinac 2016.

6. https://esavjetovanja.gov.hr/Econ/MainScreen?EntityId=4310, 18 siječanj 2017.

7. http://www.unesco.org/new/en/safeguarding-syrian-cultural-heritage/internationalinitiatives/emergency-safeguarding-of-syria-heritage/, 30. prosinac 2016.

8. http://en.unesco.org/news/director-general-irina-bokova-firmly-condemns-destructionpalmyra-s-ancient-temple-baalshamin, 30. prosinac 2016.

Međunarodni ugovori

1. UNESCO Konvencija o mjerama za zabranu i sprečavanje nezakonitog uvoza, izvoza te prijenosa vlasništva na kulturnim dobrima, Pariz, 14. studeni 1970.

2. UNIDROIT konvencija o ukradenim ili nezakonito izvezenim kulturnim dobrima, Rim, 24. lipanj 1995.

Nacionalno zakonodavstvo

Belgija, Kraljevina

1. Zakon o međunarodnom privatnom pravu od 16. srpnja 2004. (Moniteur belge, 27. srpanj 2004, str. 57344) 
Hrvatska, Republika

1. Kazneni zakon, NN br. $125 / 11,144 / 12,56 / 15,61 / 15$

2. Ustav Republike Hrvatske, NN br. 56/90, 135/97, 8/98, 113/00, 124/00, 28/01, 41/01, 55/01, 76/10, 85/10, 05/14

3. Zakona o muzejima, NN 110/15

4. Zakon o obveznim odnosima, NN 35/05, 41/08, 125/11, 78/15

5. Zakon o osnovnim vlasničkopravnim odnosima, SL SFRJ 6/1980, 36/1990, NN br. 53/1991, 91/1996

6. Zakon o vlasništvu i drugim stvarnim pravima, NN br. 91/96, 68/98, 137/99, 22/00, $73 / 00,129 / 00,114 / 01,79 / 06,141 / 06,146 / 08,38 / 09,153 / 09,143 / 12,152 / 14$

7. Zakon o zaštiti i očuvanju kulturnih dobara, NN br. 69/99, 151/03, 157/03, 100/04, $87 / 09,88 / 10,61 / 11,25 / 12,136 / 12,157 / 13,152 / 14,98 / 15$

Italija, Republika

1. Codice civile, knjiga III, poglavlje VIII, GU n.79 od 4. travnja 1942

Praksa Suda EU

1. $7 / 68$, Komisija Europskih zajednica protiv Italije (Italian Art Treasures), EU:C:1968:51 Nacionalna sudska praksa

1. Republic of Iran v. Barakat Galleries [2007] EWCA Civ 1374 
Summary

\section{PROTECTION OF CULTURAL GOODS THROUGH PROPERTY LAW AND CUSTOMS LAW IN LIGHT OF EUROPEAN COUNTERRORISM POLICY}

The paper discusses international, European, and Croatian rules on cultural goods trade. The authors critically approach the fact that said rules have not recognized the importance of property law mechanisms in fighting illegal trade in cultural goods. The paper addresses the problem of cultural goods export into third countries and EU reactions to the Iraqi and Syrian crises in terms of cultural goods importation. The authors reflect on existing internal regulation of cultural goods movement within the context of free movement of goods, and analyze restrictions to cultural goods transactions in Croatian law. The paper concludes that the Croatian system of cultural goods trade has created an adequate framework for the fight against cultural goods trafficking and that it contributes to European counterterrorism policy, noting however there remains room for improvement, particularly in the field of private law. Highlighted issues include the principle of lex rei sitae as the relevant connecting factor for cultural goods acquisition, as well as questions linked to traditional doctrines of bona fide purchase and adverse possession. The paper sets out several recommendations for the future system of protection of cultural property through import regulation.

Keywords: cultural goods, lex rei originis, counterterrorism policy, bona fide purchase.

\section{SCHUTZ VON KULTURWAREN DURCH EIGENTUMSRECHT UND ZOLLRECHT IM LICHT DER EUROPÄISCHEN ANTI-TERRORISMUS POLITIK}

Dieser Artikel diskutiert internationale, europäische und kroatische Regeln für den Kulturgüterhandel. Die Autoren beobachten kritisch die Tatsache, dass diese Regeln nicht die Bedeutung der Mechanismen des Rechtsschutzes bei der Bekämpfung des illegalen Handels mit Kulturgütern erkannt haben. Dieser Artikel behandelt das Problem des Kulturgüterexports in Drittländern und die Reaktionen der EU auf die irakische und syrische Krise im Hinblick auf die Einfuhr von Kulturgütern. Die Autoren befassen sich auch mit der bestehenden internen Regulierung der Kulturgüterbewegung im Rahmen des freien Warenverkehrs und analysieren die Beschränkungen für Kulturgütergeschäfte im kroatischen Recht. Es wird beschlossen, dass das kroatische System des Kulturgüterhandels einen angemessenen Rahmen für 
die Bekämpfung des Kulturgüterhandels geschaffen hat und dass es zur europäischen Politik der Terrorismusbekämpfung beiträgt, wobei jedoch vor allem im Bereich des Privatrechts Raum für Verbesserungen besteht. Hervorgehobene Probleme sind das Prinzip der lex rei sitae als relevanter Kopplungsfaktor für den Erwerb von Kulturgütern sowie Fragen, die mit traditionellen Doktrinen des bona fiden Kaufs und des negativen Besitzes verbunden sind. Der Artiekl enthält mehrere Empfehlungen für das künftige System des Schutzes von Kulturgütern durch Importregulierung.

Schlüsselwörter: Kulturgüter, lex rei originis, Anti-Terrorismus Politik, bona fide Kauf.

Riassunto

\section{LA TUTELA DEI BENI CULTURALI NEL DIRITTO REALE E NEL DIRITTO DOGANALE ALLA LUCE DELLA POLITICA ANTITERRORISTICA EUROPEA}

Nel lavoro si analizzano le regole internazionali, europee e croate nell'ambito della circolazione dei beni culturali. Gli autori riflettono criticamente sul fatto che queste tali regole non abbiano riconosciuto l'importanza dei meccanismi del diritto reale nella lotta contro il traffico illegale dei beni culturali. Si esamina il problema dell'esportazione dei beni culturali in paesi terzi e le reazioni dell'UE sulla crisi irachena e siriana con riguardo all'importazione di beni culturali. Si discute di nuove misure UE con riguardo alla regolazione dell'importazione dei beni culturali da paesi terzi come parte dell'agenda onnicomprensiva nella lotta al finanziamento del terrorismo. Gli autori prestano attenzione alla disciplina esistente del traffico interno dei beni culturali nel contesto della libertà di circolazione delle merci ed analizzano le limitazioni della circolazione giuridica dei beni culturali nel diritto croato. Se ne conclude come il regime croato della circolazione dei beni culturali abbia creato una valida cornice per la lotta contro il traffico illecito dei beni culturali e come questo già ora dia un valido apporto alla realizzazione delle politica antiterrorismo dell'UE; tuttavia si rileva come ci sia sempre spazio per migliorare le soluzioni esistenti specialmente nell'ambito della sfera privatistica. Al riguardo si vagliano con particolare attenzione le questioni riguardanti la scelta della lex rei sitae quale statuto di diritto reale per i beni culturali, come pure le questioni riguardanti gli istituti tradizionali volti all'acquisto $a$ non domino ed all'usucapione. Nel lavoro si avanzano alcuni suggerimenti volti alla protezione futura dei beni culturali all'atto dell'importazione.

Parole chiave: beni culturali, lex rei originis, politica antiterrorismo, acquisto a non domino. 